\title{
Mineral chemistry and formation conditions of calc-silicate minerals of Qozlou Fe skarn deposit, Zanjan Province, NW Iran
}

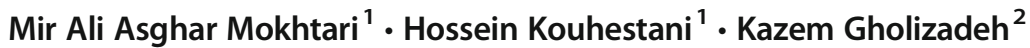

Received: 24 November 2018 / Accepted: 5 September 2019/ Published online: 27 October 2019

(C) The Author(s) 2019

\begin{abstract}
The Qozlou Fe skarn deposit is located at the Abhar-Mahneshan belt of the Central Iranian Zone. It is associated with Upper Eocene porphyritic granite that intruded into the Upper Cretaceous impure carbonaceous rocks. The Qozlou granite has high-K calc-alkaline affinity and is classified as subduction-related metaluminous I-type granitoids. Skarn aureole in the Qozlou is composed of endoskarn and exoskarn zones, with the exoskarn zone being the main skarn and mineralized zone. It includes garnet skarn, garnet-pyroxene skarn, pyroxene skarn, epidote skarn, and pyroxene-bearing marble sub-zones. The Qozlou Fe deposit is $300 \mathrm{~m}$ long and 5-30 m wide. Magnetite is the main ore mineral associated to pyrite, chalcopyrite, and pyrrhotite. Garnet, clinopyroxene, actinolite, epidote, calcite, and quartz occur as gangue minerals. Covellite, hematite, and goethite were formed during the supergene processes. The ore and gangue minerals have massive, banded, disseminated, brecciated, veinveinlets, replacement, and relict textures. EPMA data indicate that garnets have andradite-grossularite compositions $\left(\mathrm{Ad}_{39.97-}\right.$ $\left.{ }_{100}-\mathrm{Gr}_{0-49.62}\right)$ and clinopyroxenes have diopsidic composition $\left(\mathrm{En}_{29.43-42.5}-\mathrm{Fs}_{14.31-20.99}-\mathrm{Wo}_{43.08-50.17}\right)$. Based on mineralogical and textural criteria, skarnification processes in the Qozlou skarn can be categorized into three discrete stages: (1) isochemical (metamorphic-bimetasomatic), (2) metasomatic prograde, and (3) metasomatic retrograde. Anhydrous calc-silicate minerals (garnet and clinopyroxene) were formed during the prograde metasomatic stage, while ore minerals and hydrous calc-silicate minerals were formed during the retrograde ore-forming sub-stage. Temperature and $f \mathrm{O}_{2}$ conditions range between 430 and 550 ${ }^{\circ} \mathrm{C}$ and $10^{-26}$ and $10^{-23}$, respectively, for the metasomatic prograde stage. The retrograde metasomatizing fluids had likely $f \mathrm{~S}_{2}=$ $10^{-6.5}$ and temperatures $<430^{\circ} \mathrm{C}$ at the beginning of the ore-forming sub-stage.
\end{abstract}

Keywords Mineral chemistry $\cdot$ Fe skarn $\cdot$ Qozlou $\cdot$ Abhar $\cdot$ Mahneshan $\cdot$ Zanjan $\cdot$ Iran

\section{Introduction}

Skarn deposits are one of the more abundant ore types in the earth's crust and formed in rocks of almost all ages (Einaudi et al. 1981; Meinert et al. 2005). Skarn is a relatively simple rock type defined by a mineralogy usually dominated by calcsilicate minerals such as garnet and pyroxene (Einaudi et al. 1981; Meinert 1997). Although the majority of skarns are

Responsible Editor: Domenico M. Doronzo

Mir Ali Asghar Mokhtari

amokhtari@znu.ac.ir

1 Department of Geology, Faculty of Sciences, University of Zanjan, Zanjan 45195-313, Iran

2 EPMA Laboratories, Iranian Mineral Processing Research Center (IMPRC), Karaj 91995-135, Iran found in lithologies containing at least some limestone, they can form in almost any rock type during contact metamorphism and from a variety of metasomatic processes involving fluids of magmatic, metamorphic, meteoric, and/or marine origin (Meinert et al. 2005). Skarn deposits can be grouped on the basis of descriptive features such as protolith composition, rock type, or dominant economic metal(s) as well as genetic features such as mechanism of fluid movement, temperature of formation, and extent of magmatic involvement (Meinert et al. 2005). Seven major skarn types (Fe, Au, W, $\mathrm{Cu}, \mathrm{Zn}, \mathrm{Mo}$, and $\mathrm{Sn}$ ) have received significant modern study, and several others (including F, C, Ba, Pt, U, and REE) are locally important (Meinert et al. 2005). The largest skarn deposits are the Fe skarns which are mined for their magnetite content and although minor amounts of $\mathrm{Cu}, \mathrm{Co}, \mathrm{Ni}$, and $\mathrm{Au}$ may be present. Fe typically is the only commodity recovered (Einaudi et al. 1981; Grigoryev et al. 1990; Meinert 2000; Meinert et al. 2005). Many deposits are very large (> 1000 
million tons ore) and consist dominantly of magnetite with only minor silicate gangue. Some deposits contain significant amounts of $\mathrm{Cu}$ and are transitional to more typical $\mathrm{Cu}$ skarns (e.g., Kesler 1968; Vidal et al. 1990; Meinert et al. 2005; Pirajno 2009).

Fe skarn deposits in Iran were formed mainly during the Cenozoic (Nabatian et al. 2017). These deposits are mainly located in the Alborz-Azarbaijan magmatic belt (AAMB), Urumieh-Dokhtar magmatic arc (UDMA), Sanandaj-Sirjan zone (SSZ), and Central Iranian zone (CIZ). Most of the Fe skarn deposits are related to the Cenozoic magmatism which occurred during the subduction and closure of the NeoTethyan Ocean (Nabatian et al. 2017).

Fe skarn deposits are one of the well-known Fe resources in the Abhar-Mahneshan belt of Zanjan Province, northwestern Iran, which are exploited during the past decades. These deposits are the result of granitoid intrusions within the carbonaceous rocks. Some of the most important Fe skarn deposits in Zanjan Province include Arjin (Andarz 2006; Besharati et al. 2010), Qozal Darreh (Mohammadi 2013), Bashkand (Shahbazi et al. 2015), Alamkandi (Nouri et al. 2017), Qovaq (Mohammad Beigi et al. 2016), Khakriz (Fakhr Shafaie et al. 2015), and Inche Rahbari (Hamidvand et al. 2015). The Shahrak Fe deposit in Kurdistan Province and Qovaq Fe deposit were reported as skarn-type deposit with several million tons reserve (Maanijou and Salemi 2014). The Qozlou Fe skarn deposit $(\sim 250,000$ tone resource of magnetite $\mathrm{Fe}$ ore with an average grade of $\mathrm{Fe}_{\mathrm{t}} \sim 50 \%$ ), $65 \mathrm{~km}$ west of Zanjan, was hosted by late Cretaceous flysch type rocks that were intruded by Qozlou granitoid. Except for small-scale geological maps of the area, i.e., 1:100,000 geological map of Mahneshan (Lotfi 2001) and an unpublished company exploration report (Hosseini 2008), studies of the Qozlou Fe skarn deposit have been limited and include publications by Shafaiepour et al. (in press) and Shafaiepour (2018). These studies mostly focused on the origin of the deposit. In this contribution, we present the first petrographic study of skarn zones, mineral chemistry, and formation condition of calc-silicate minerals from the Qozlou deposit. Our results extend knowledge of the geodynamic framework and formation of Fe skarn mineralization in the AbharMahneshan belt, and provide exploration criteria for similar Fe skarn ores in this area and other parts of the CIZ in northwestern Iran.

\section{Geological background}

The Zagros orogeny is a part of the Alpine-Himalayan orogenic belt in Iran which resulted from the closure of the NeoTethyan Ocean between the Afro-Arabian and Eurasian plates (Berberian and King 1981; Șengör et al. 1988; Alavi 2007; Agard et al. 2011). This orogen extends from eastern Turkey
(Bitlis suture zone) through northern Iraq and southwestern Iran into northern Oman, and contains three parallel tectonic zones in Iran including the UDMA, SSZ, and Zagros foldand-thrust belt (Alavi 2004).

Subduction of the Neo-Tethyan Ocean beneath the Eurasian and Iranian plates caused the formation of the AAMB, UDMA, SSZ, and Zagros fold-and-thrust belt (Berberian and King 1981; Mohajjel et al. 2003). In general, the Neo-Tethyan subduction is widely considered as the key process that operated from the Jurassic to the Tertiary to form the arc magmatism not only in the UDMA (e.g., Berberian and King 1981; Alavi 1994; Omrani et al. 2008; Verdel et al. 2011), but also in the SSZ (e.g., Mohajjel et al. 2003; Baharifar et al. 2004; Ghasemi and Talbot 2006; Arvin et al. 2007; Aghazadeh et al. 2010; Hassanzadeh and Wernicke 2016). During this time, subduction of the oceanic crust caused widespread magmatic activity throughout the Iranian plateau especially in the CIZ, AAMB, UDMA, SSZ, and eastern Iran (Agard et al. 2005, 2011; Verdel et al. 2011; Chiu et al. 2013; Asiabanha and Foden 2012; Honarmand et al. 2014; Nabatian et al. 2014). Although their ages range from the Eocene to the Quaternary, their temporal distribution is focused into several pulses of magmatism in the Eocene, Miocene, and Plio-Quaternary (Asiabanha and Foden 2012; Aghazadeh et al. 2015). This magmatic activity was responsible for different mineralization styles such as porphyry $\mathrm{Cu}-$ Mo, epithermal $\mathrm{Au}-\mathrm{Cu}-\mathrm{Pb}-\mathrm{Zn}$, Kiruna-type IOA deposits, orogenic gold, and skarn-type deposits in the Iranian plateau.

The UDMA in Iran with more than $2000 \mathrm{~km}$ length and $100 \mathrm{~km}$ width (Fig. 1a) is an Andean-type magmatic arc (Takin 1972; Berberian et al. 1982; Șengör 1990; Alavi 1994) associated with the subduction of the Neo-Tethyan oceanic lithosphere beneath Central Iran (Shahabpour 2005; Richards et al. 2006; Arvin et al. 2007; Omrani et al. 2008). It consists of voluminous volcanic successions, with minor intrusive rocks. The volcanic successions are composed largely of calc-alkaline rocks (Berberian and Berberian 1981; Alavi 2007). Most volcanic rocks belong to the Eocene and the Oligocene (Shahabpour 2005; Verdel et al. 2011; Chiu et al. 2013), whereas intrusions are generally Upper Eocene and Oligo-Miocene (Berberian and Berberian 1981; Chiu et al. 2013).

The Abhar-Mahneshan belt at northwestern CIZ and UDMA (Fig. 1b), in the hinterland of the Zagros orogeny, is flanked by the AMB in the north-northeast and the SSZ to the south. This belt consists of large crustal blocks which are mainly underlain by Late Proterozoic to Jurassic strata, volcano-sedimentary rocks of the Eocene, and finally Oligocene-Miocene sedimentary rocks. These rock units consist of the Kahar, Bayandor, Soltanieh, Barut, Zagun, Lalun, Mila, Doroud, Ruteh, Shemshak, Lar, Karaj, Lower Red, Qom, and Upper Red formations. The Abhar-Mahneshan belt was intruded by the following two episode granitic plutons: 


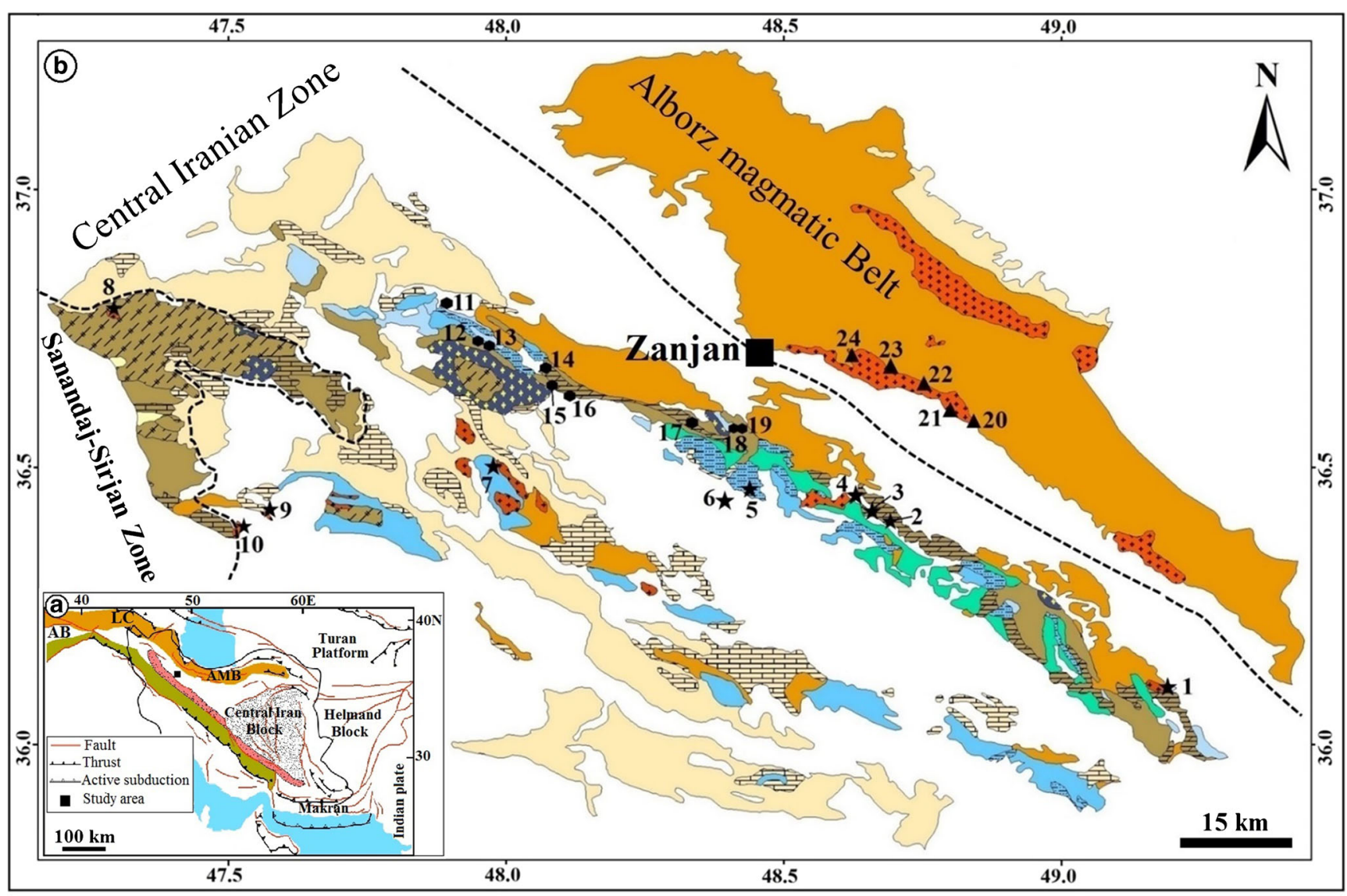

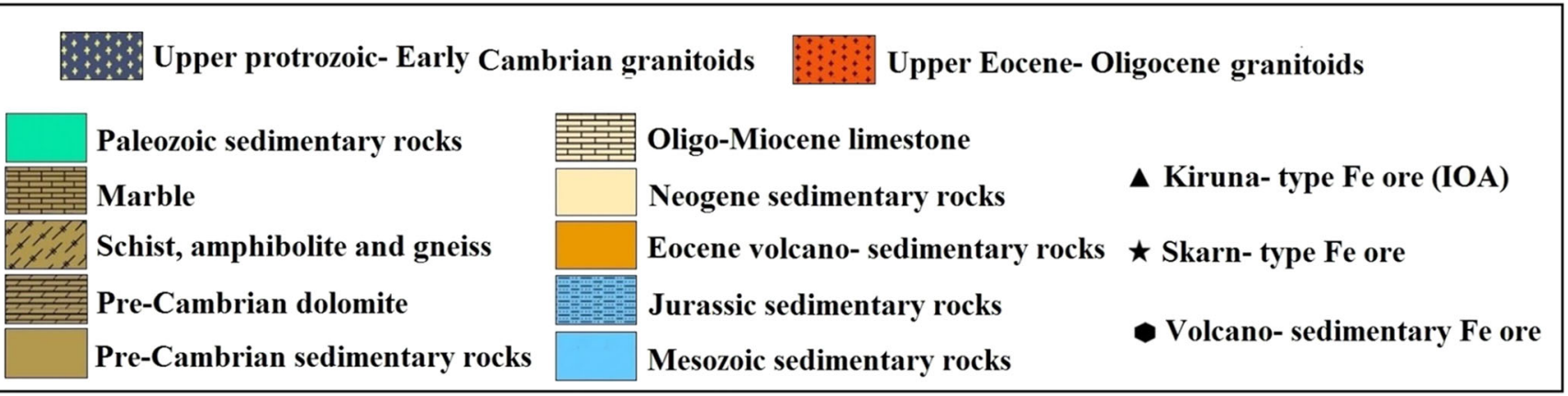

Fig. 1 a, Simplified structural map of Iran and adjacent regions and location of Tethyan sutures (modified after Ramezani and Tucker 2003). Location of the study area is shown by a small black square; $b$, simplified geological map of the Abhar-Mahneshan belt and adjacent zones showing the location of Fe deposits in the Abhar-Mahneshan belt and AMB. 1, Kouhjin; 2, Arjin; 3, Bashkand; 4, Qozal Darreh; 5, Khakriz; 6, Inche Rahbari; 7, Qozlou; 8, Alamkandi; 9, Qovaq; 10,
Shahrak; 11, Qazikandi; 12, Torpakhlou; 13, Mirjan; 14, Goljic; 15, Kavand; 16, Hossein Abad; 17, Chavarzaq; 18, Reyhan; 19, Azhdehatou; 20, Sorkheh Dizaj; 21, Morvarid; 22, Zaker; 23, Golestan Abad; 24, Zarnan; LC, Lesser Caucasus; AB, Anatolian Block; AMB, Alborz magmatic belt; UDMA, Urumieh-Dokhtar Magmatic Arc; MZTF, Main Zagros thrust-fold belt

as gangue minerals (Ghorbani 2013). The most important deposits include Reyhan, Azhdehatou and Chavarzaq (south of Zanjan), Shah Bolaghi, and Kavand (southwest of Zanjan), Mirjan, Goljic, Torpakhlou, and Qazikandi (northwest of Zanjan) deposits (Fig. 1b). On the other hand, there are some skarn-type Fe mineralizations within the Abhar-Mahneshan belt (e.g., Kouhjin, Arjin, Bashkand, Qozal Darreh, Khakriz, Inche Rahbari, and Qozlou) which are related to Upper Eocene-Oligocene granitic intrusion (Fig. 1b). Furthermore, magnetite, and siderite along with calcite, dolomite, and barite 
there are some Kiruna-type Fe deposits (IOA) in the east and southeast of Zanjan within the AMB (Fig. 1b) which are not related to the subject of this paper.

\section{Geology of the Qozlou Fe deposit}

The oldest rock units in the Qozlou area are composed of 500 $700 \mathrm{~m}$ alternation of Upper Cretaceous shale, sandstone, marl, marly limestone, and grey-colored fossiliferous limestone (Lotfi 2001). These rocks are the host rock of Fe mineralization and crop out at the southern part of the Qozlou Fe deposit (Fig. 2). Upper Cretaceous rocks are covered unconformably by Lower Oligocene red-colored, coarse-grained detrital deposits of the Lower Red Formation (LRF) (Lotfi 2001), which crop out in the northern part of the Qozlou Fe deposit (Fig. 2). They are composed of conglomerate at the base and alternation of red-brown sandstone, marl, and shale with about 800 $\mathrm{m}$ thickness. The base conglomerate is polymictic and consists of mainly Paleozoic, Mesozoic, and Eocene sedimentary, volcanic, and intrusive rocks set in a sandy matrix. Alternation of the medium to thick-bedded cream-colored biomicritic reefal fossiliferous limestone with marl intercalation conformably cover the LRF in the study area (Fig. 2). This rock unit is considered as Qom Formation (QF), and its thickness is 50 $200 \mathrm{~m}$ (Lotfi 2001). The presence of different kinds of microfossils demonstrates that these rocks were deposited in a marine environment during the Upper Oligocene-Lower Miocene (Lotfi 2001). The rocks of QF crop out at the northwestern, northeastern, and eastern parts of the Qozlou Fe deposit (Fig. 2). Rock units of the QF are conformably covered by an alternation of red and green marls and sandstones of the Upper Red Formation (URF) (Lotfi 2001). There is an evaporatic key layer (gypsum and salt) at the lower part of this unit which separates URF from marine QF. There are some salt (Douzkand mine) and boron (Qara Qol mine) mines in this unit. The rocks of the URF crop out at the northeastern and western parts of the Qozlou Fe deposit (Fig. 2). Finally, a sequence of consolidated to unconsolidated Pliocene polymictic conglomerate with 60-200-m thickness covers the older rocks.

There are two types of granitoid intrusions around the study area including (1) Upper Proterozoic-Early Cambrian Moghanlou granitoid (Lotfi 2001; Hassanzadeh et al. 2008; Honarmand et al. 2018) and (2) post Cretaceous Qozlou granitoid (Lotfi 2001). Moghanlou granitoid with an area about $100 \mathrm{~km}^{2}$ is anatectic granite that intruded into the Precambrian Kahar Formation (Lotfi 2001). It can be classified into three portions (Lotfi 2001): (1) the central part, mineralogically composed of quartz, perthitic feldspars, and biotite and having granite composition; (2) the middle part, composed of pneumatolitic minerals like perthitic feldspars, quartz, muscovite, and biotite, and having pegmatite composition; and (3) the outer part, comprising the highly argillaceous altered zone. The zircon $\mathrm{Hf}$ and bulk rock $\mathrm{Sr}-$ $\mathrm{Nd}-\mathrm{Pb}$ isotopic data suggest that the Moghanlou granitoid plutons were generated by partial melting of continental crust (Honarmand et al. 2018). The Qozlou granitoid intruded into the Upper Cretaceous rocks and was covered unconformably by rock units of the LRF (Lotfi 2001; Shafaiepour et al. in press). This intrusion led to the contact metamorphism and formation of the Qozlou Fe skarn deposit. Mineralogically, this intrusion consists of plagioclase, K-feldspar, quartz, hornblende, and biotite with some clinopyroxene, and has porphyritic granite composition (Shafaiepour 2018; Shafaiepour et al. in press). The Qozlou granitoid has high-K calc-alkaline affinity and is classified as subduction-related metaluminous Itype granitoids (Shafaiepour 2018; Shafaiepour et al. in press). The age of this intrusion is not exactly specified, but new researches on some similar intrusions in Khakriz and Inche Rahbari area indicate that they are Upper Eocene in age (52$55 \mathrm{Ma}$; Hassanzadeh et al. 2008; Nabatian et al. 2017; Mokhtari et al. 2018). Based on field relationships, Upper Eocene age can be considered for the Qozlou porphyritic granite.

The main structures at the Qozlou Fe deposit area are a NW-SE-trending thrust and strike-slip fault systems (Fig. 2). Most of the faults were located with Upper Cretaceous rocks which could have had an important role in the evolution of Fe mineralization. Structurally, the Qozlou Fe deposit area is a NW-SE anticline with Qozlou granite intrusion along its axis (Fig. 2).

The Qozlou porphyritic granite intruded into the Upper Cretaceous rocks which led to contact metamorphism and Fe skarn mineralization (Fig. 3a). Magnetite is the main ore mineral of this mineralization. Skarn aureole at the Qozlou area is composed of endoskarn and exoskarn zones (Fig. 3a), and Fe mineralization is mainly restricted to the exoskarn zone. The Qozlou Fe deposit has $300 \mathrm{~m}$ length and 5-30 m width and crops out in the southeastern margin of the Qozlou porphyritic granite. In some places, there are enclaves of Upper Cretaceous host rock within the granite which are metamorphosed and $\mathrm{Fe}$ mineralization was formed (Fig. 3b). A coarse-grained idiomorphic garnet-bearing $\mathrm{Fe}$ mineralization sub-zone (Fig. $3 \mathrm{c}$ ) with $2 \mathrm{~m}$ thickness is present within the $\mathrm{Fe}$ ore zone. Garnet crystals' size reaches up to $3 \mathrm{~cm}$ (Fig. 3c). Sulfide mineralization (mainly pyrite) presents as vein-veinlets, banded and disseminated form within the Fe ore zone (Fig. 3d). This means that the sulfide mineralization stage is formed later than magnetite mineralization. Late-stage quartz and calcite vein-veinlets crosscut the $\mathrm{Fe}$ and sulfide mineralization (Fig. 3e).

Based on the field and petrographic studies, two zones, i.e., exoskarn and endoskarn, can be distinguished at the Qozlou Fe deposit. The endoskarn zone occurs within the 


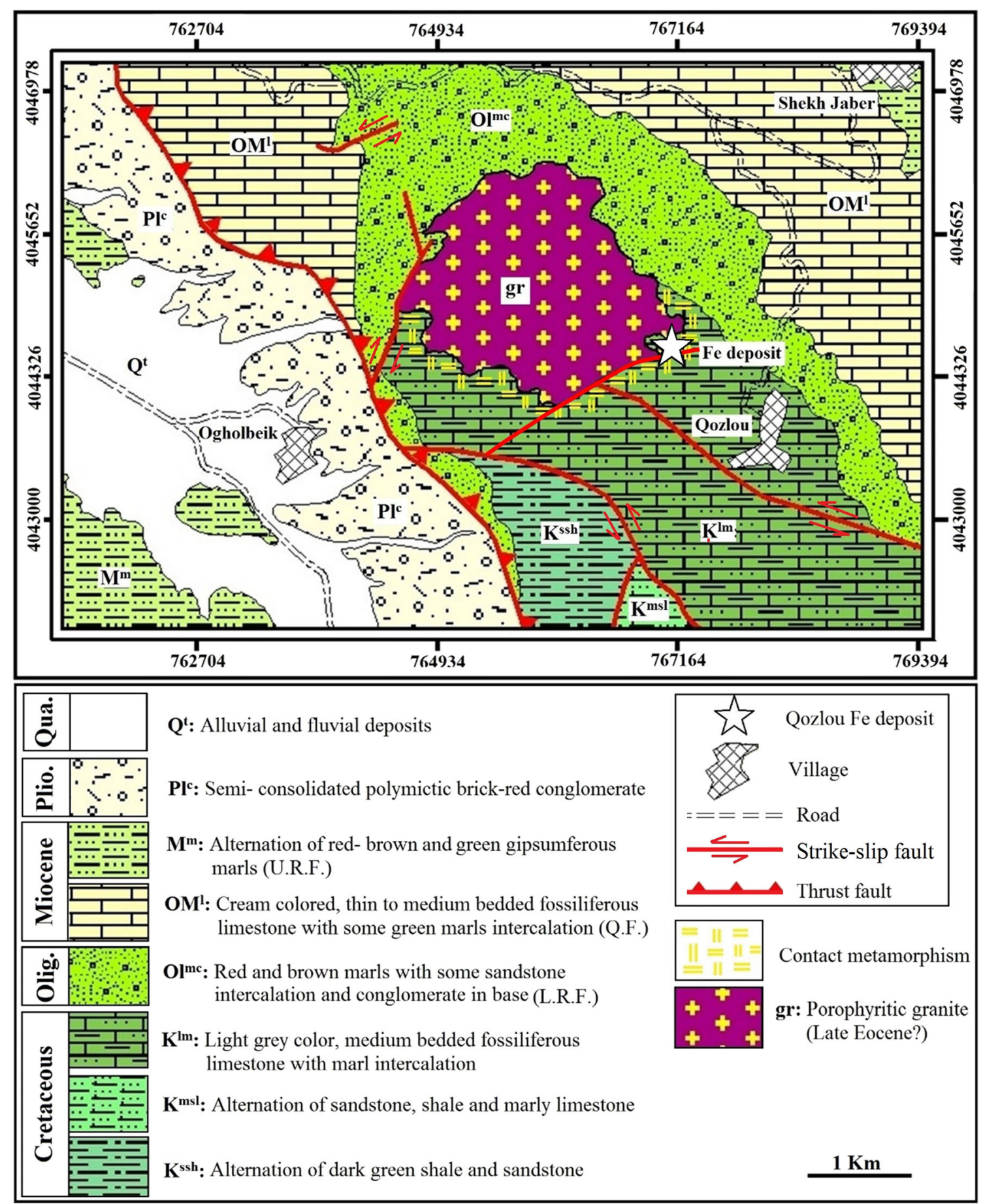

Fig. 2 Geological map of the Qozlou Fe deposit

granite and is composed of plagioclase, clinopyroxene, actinolite, biotite, and opaque minerals (Fig. 4a). The exoskarn zone is the main skarn and mineralized zone that mineralogically includes garnet skarn, garnet-pyroxene skarn, pyroxene skarn, epidote skarn, and pyroxenebearing marble sub-zones. Fe mineralization along with some sulfide minerals is present within the garnet, garnet-pyroxene, and pyroxene skarn sub-zones while epidote skarn and pyroxene-bearing marble sub-zones only have some sulfide mineralization.

The garnet skarn sub-zone is located at the contact of the granite and is composed mainly of garnet with some clinopyroxene, actinolite, calcite, epidote, quartz, and opaque minerals. Garnet occurs as euhedral to subhedral fine to coarse-grained crystals $(0.5-1 \mathrm{~cm})$, though it can be very coarse-grained $(>3 \mathrm{~cm})$. The garnets are 
Fig. 3 a A view from the skarn aureole and $\mathrm{Fe}$ mineralization in the contact of Qozlou granite, looking to the west; $\mathbf{b}$ a view from the skarn and Fe mineralization as enclaves within granite, looking to the north; $\mathbf{c}$ close view from idiomorphic crystals of garnet with magnetite ore; $\mathbf{d}$ close view from pyrite mineralization with banded and disseminated texture within the magnetite ore; e close view from the calcite veinlet crosscutting the garnet crystals and magnetite ore. Cal, calcite; En Sk, endoskarn; gr, granite; Grt, garnet; Mag, magnetite; Py, pyrite
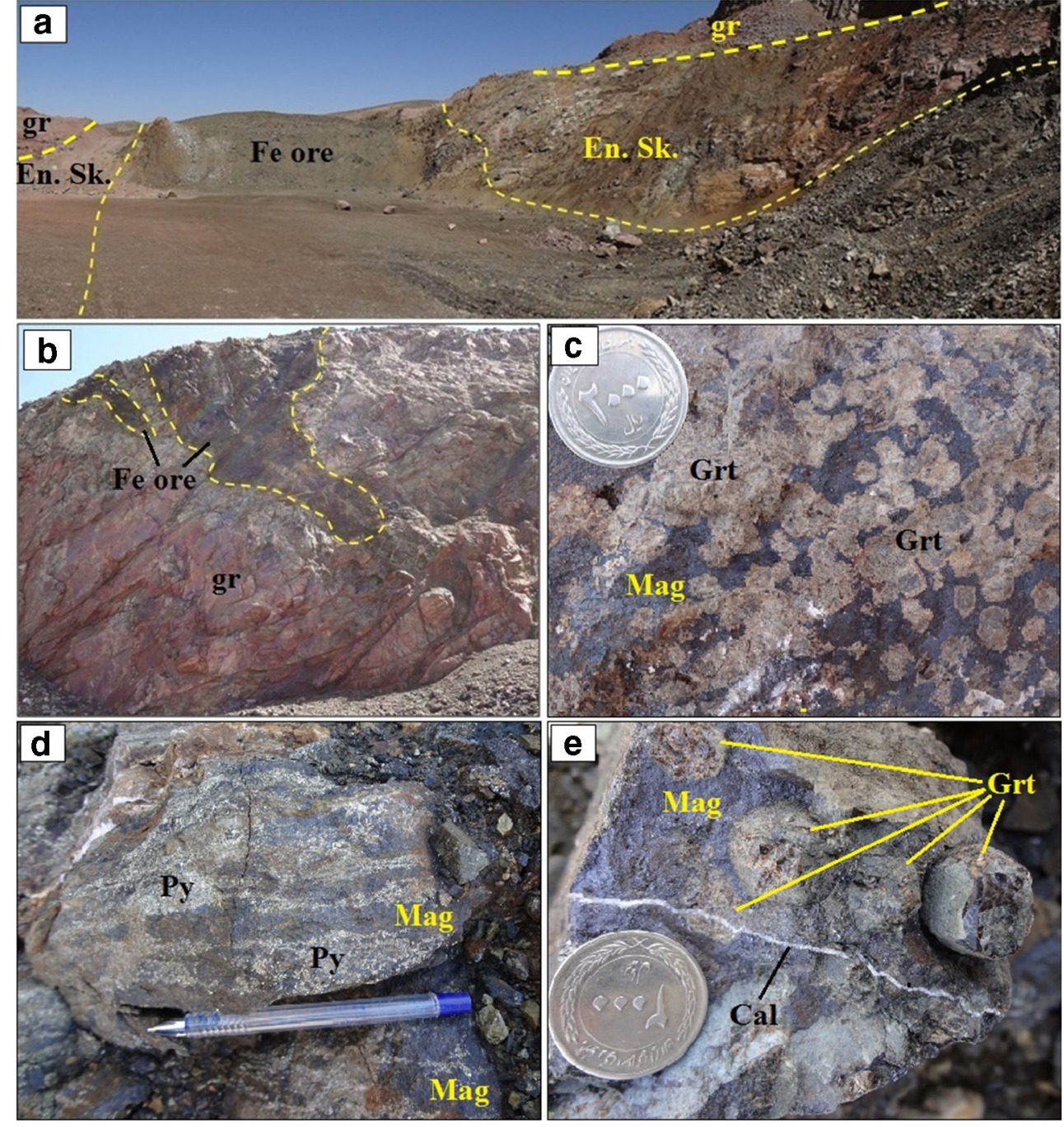

dominantly homogeneous whereas some coarse-grained crystals show concentric, oscillatory zoning (Fig. 4b). The garnets demonstrate some retrograde alteration to epidote, calcite, and quartz. Magnetite is also observed as replacements in the garnet rims and fractures. Clinopyroxene is mainly present as small inclusions (> $0.5 \mathrm{~mm}$ ) within the garnets. Furthermore, there are some clinopyroxenes between garnet crystals which are highly altered to actinolite. Opaque minerals are mainly magnetite along with some sulfide (i.e., pyrite) minerals. Some late quartz and calcite vein-veinlets cut these rocks. Also, calcite is present between the garnet crystals (Fig. 4b).

The garnet-pyroxene skarn sub-zone is located near the contact of intrusion. It contains clinopyroxene, garnet, actinolite, calcite, epidote, quartz, titanite, and opaque minerals. Garnet occurs as euhedral to subhedral homogeneous coarse-grained crystals $(1-1.5 \mathrm{~cm})$, which are highly altered to epidote, calcite, and quartz (Fig. 4c). Clinopyroxene with high degree of alteration to actinolite is mainly present as euhedral to subhedral crystals within opaque mineral matrix (Fig. 4c). Pyroxene skarn sub-zone can be seen in other parts of the contact with the intrusion consisting of clinopyroxene along with some actinolite, epidote, quartz, and opaque minerals. Clinopyroxenes occur as subhedral medium-grained crystals mainly within the opaque mineral matrix (Fig. $4 \mathrm{~d}$ ( often altered to actinolite. Furthermore, clinopyroxenes can be seen in the massive form with rare quartz and epidote.

The epidote skarn sub-zone located far away from intrusion consists of epidote and actinolite with some clinopyroxene, quartz, and $\mathrm{K}$-feldspar as accessory minerals (Fig. 4e). Opaque minerals (sulfide) present are disseminated in these rocks (Fig. 4e). Some late quartz and calcite veinlets cut these rocks. Pyroxene-bearing marbles were formed in the outer part of the skarn aureole and consist of mainly calcite $(>70 \%)$ along with some clinopyroxene, euhedral opaque minerals (pyrite), and quartz and K-feldspar as minor minerals (Fig. 4f). Clinopyroxenes are highly altered to actinolite. 

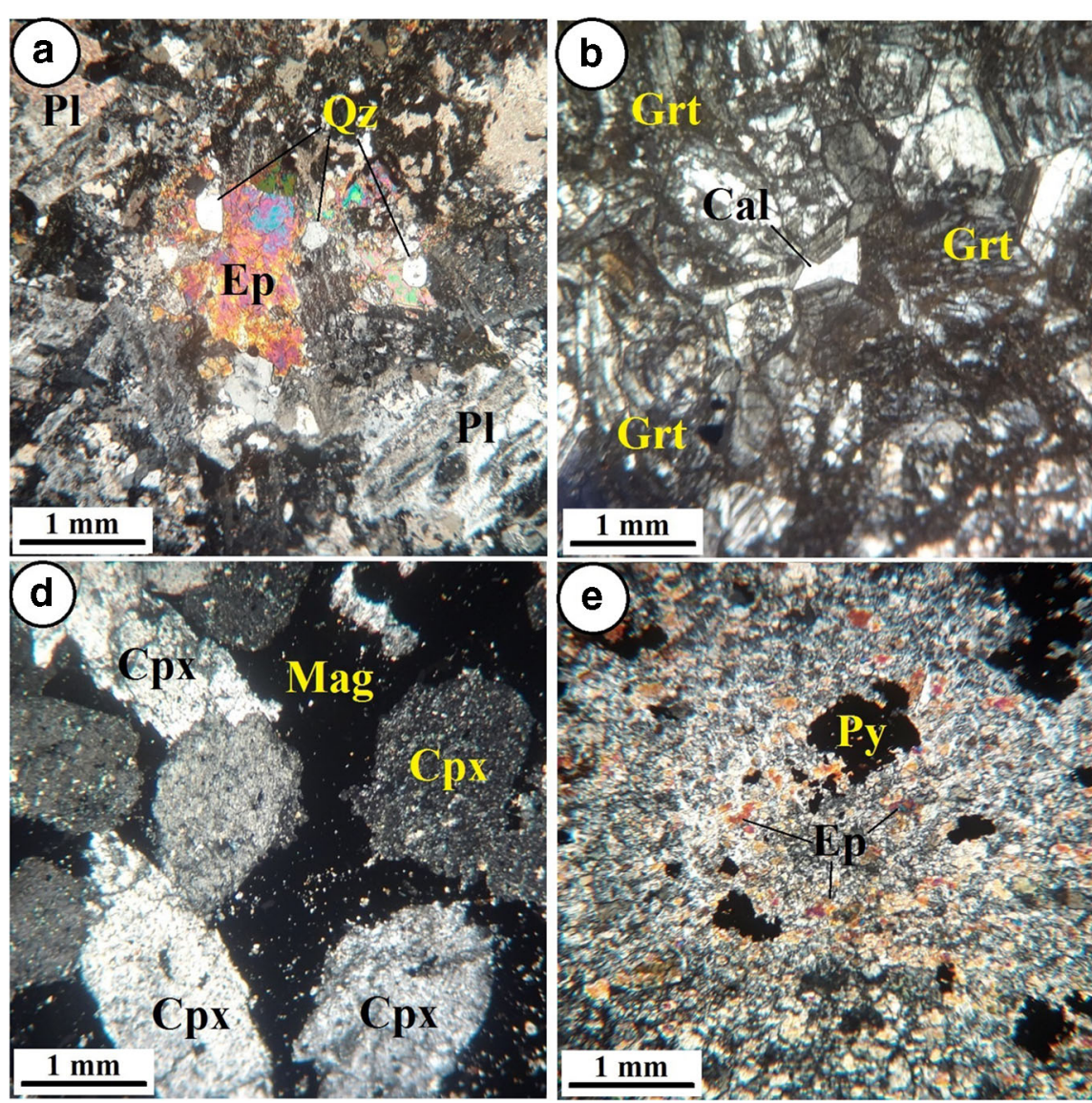

grained epidote along with opaque minerals (pyrite) in the epidote skarn sub-zone; $\mathbf{f}$ actinolitized clinopyroxene crystals along with opaque minerals (pyrite) within calcite matrix in the pyroxene-bearing marble subzone. Act, actinolite; $\mathrm{Cal}$, calcite; $\mathrm{Ccp}$, chalcopyrite; $\mathrm{Cpx}$, clinopyroxene; $\mathrm{Cv}$, covellite; En Sk, endoskarn; Ep, epidote; Gth, goethite; gr, granite; Grt, garnet; Hm, hematite; Mag, magnetite; Po, pyrrhotite; Py, pyrite garnet-pyroxene sub-zone; $\mathbf{d}$ euhedral to subhedral clinopyroxene crystals within the magnetite matrix in the pyroxene skarn sub-zone; e fine-

\section{Experimental method}

A total of 52 samples were collected from skarn aureole and Fe mineralization to undertake petrographic and mineral chemistry studies. Petrographic studies including identification of mineral assemblages, textures, alteration, and metasomatic replacements which were performed using a GX microscope at the mineralogy laboratory in the University of Zanjan on 16 thin and 16 thin-polished sections. Based on the optical microscopic observations, 5 samples from the skarn zone were selected for electron probe micro-analysis (EPMA) on the garnet and pyroxene minerals. The major oxide compositions of the mentioned minerals were determined on 63 points at the Iranian Mineral Processing Research Center (IMPRC) using a Cameca SX-100 electron microprobe equipped with 5 wavelength-dispersive crystal spectrometers, operating with $3 \mu \mathrm{m}$ beam diameter, $15 \mathrm{kV}$ accelerating voltage, $15 \mathrm{nA}$ current, and $60 \mathrm{~s}$ counting time (Tables 1 and 2). Elements were calibrated against synthetic and natural standards. Analytical measurements were affected by a relative uncertainty of $1 \%$ for major oxides, and the detection limit is approximately 100 $\mathrm{ppm}$. Chemical formulae and end-member proportions for the mineral analyses were calculated after Deer et al. (1992) for pyroxenes, and $\mathrm{Fe}^{+3}$ was calculated based on ideal stoichiometric composition.

\section{Discussion}

\section{Ore mineralogy, texture, and paragenetic sequence}

Magnetite is the main ore mineral in the Qozlou skarn deposit which is accompanied by pyrite, chalcopyrite, and pyrrhotite. Garnet, clinopyroxene, actinolite, epidote, calcite, and quartz present as gangue minerals. Covellite, hematite, and goethite were formed during the supergene processes. Ore and gangue minerals in the Qozlou Fe skarn deposit show massive, 


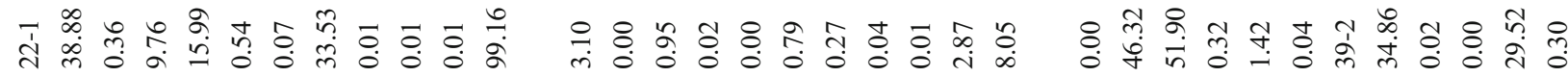

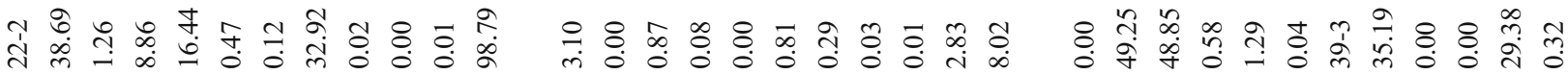

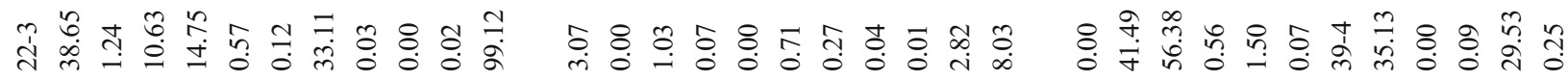

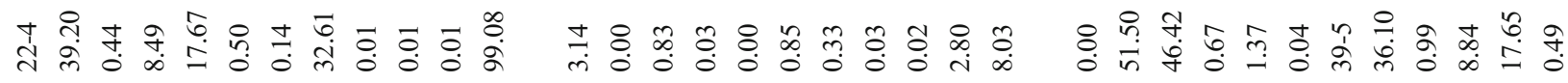

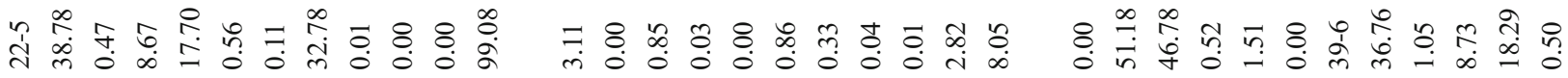

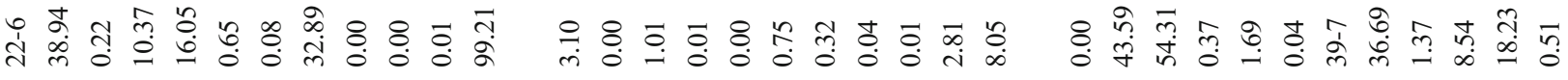

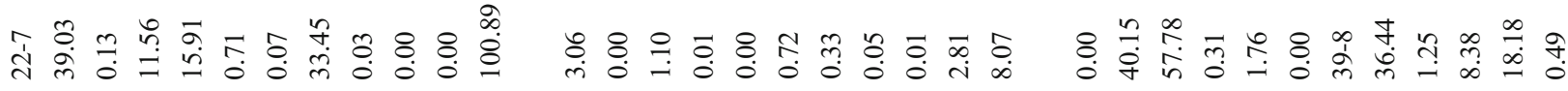

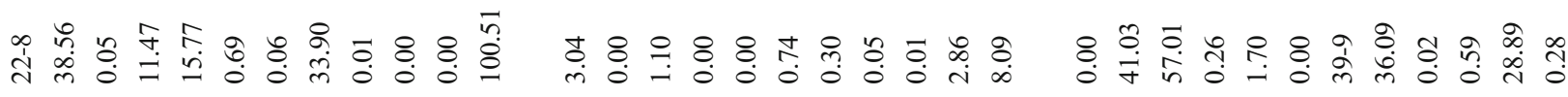

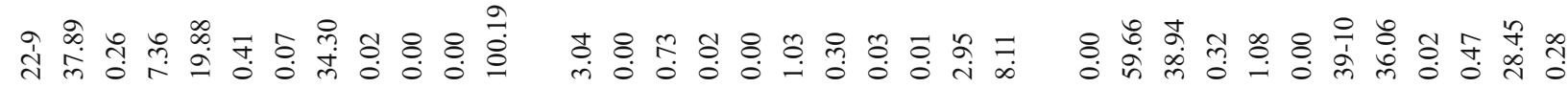

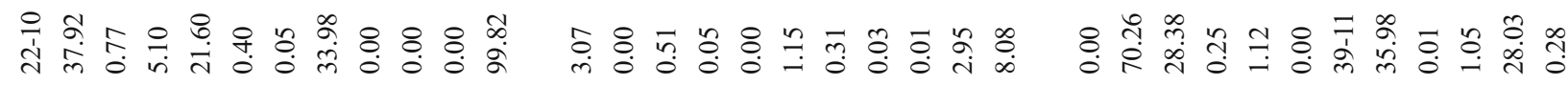

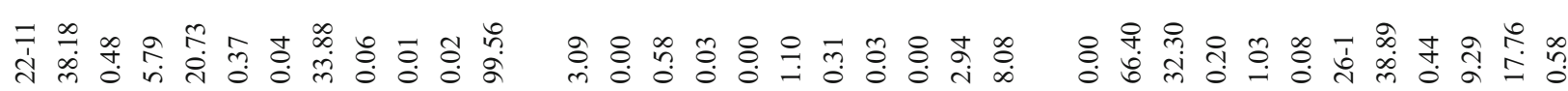

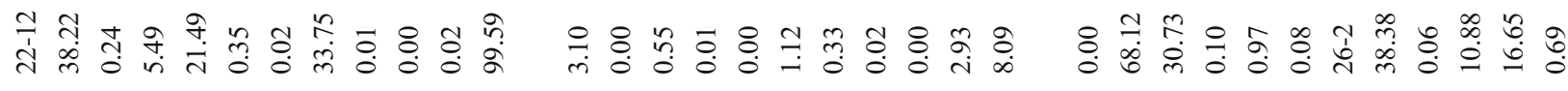

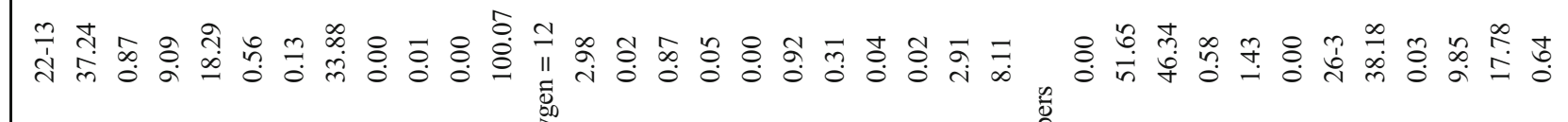

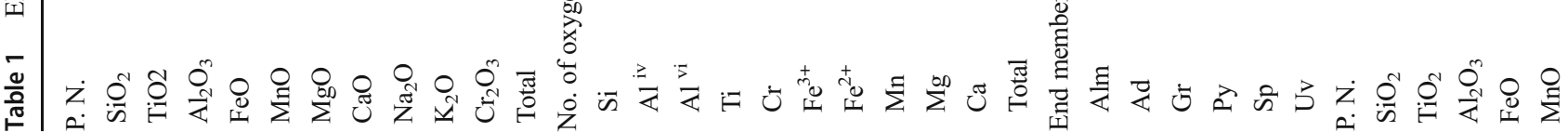




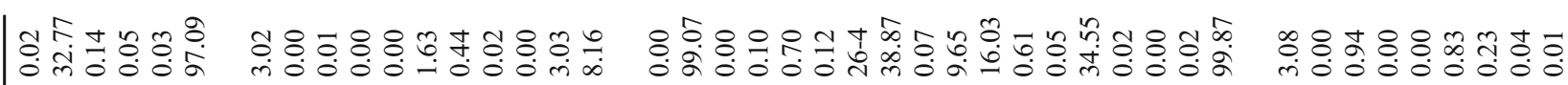

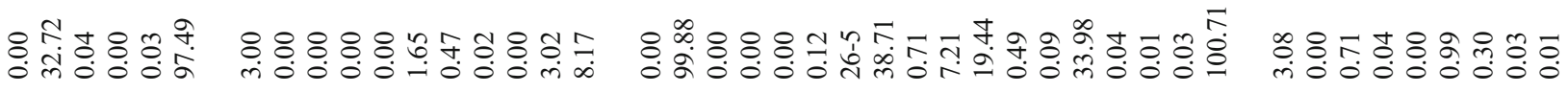

б

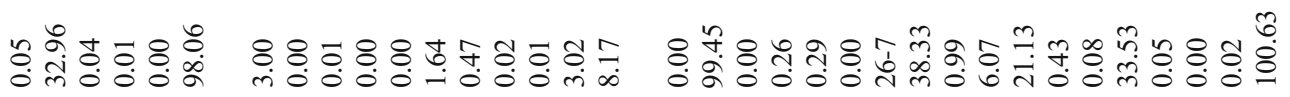

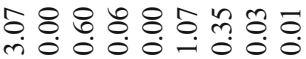

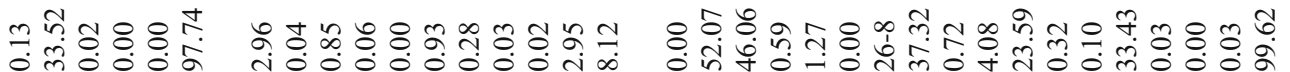

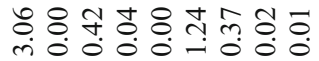

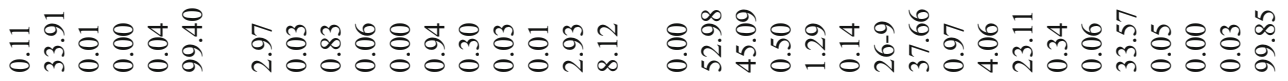

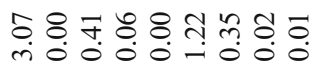
†

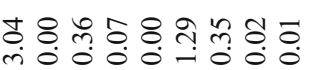

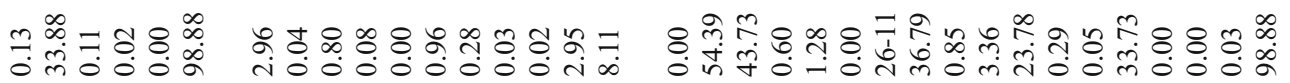

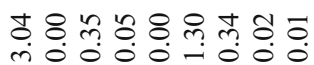

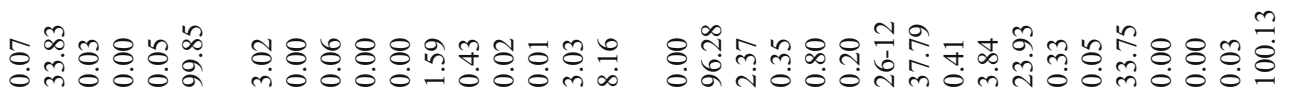

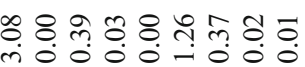
ำ ते

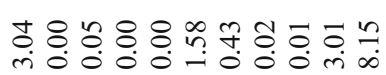

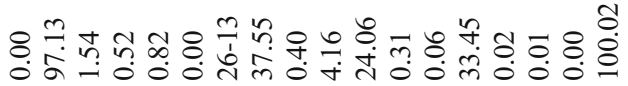

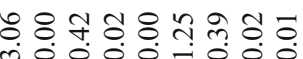

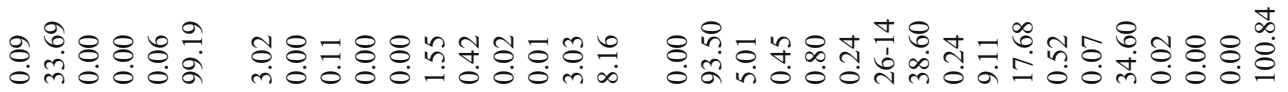

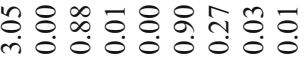

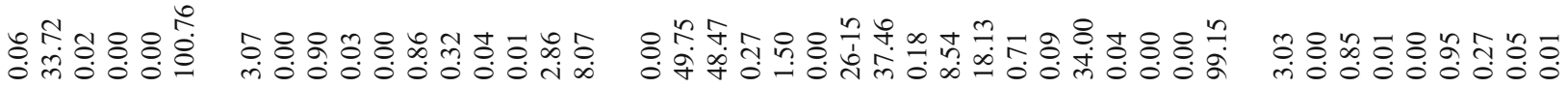

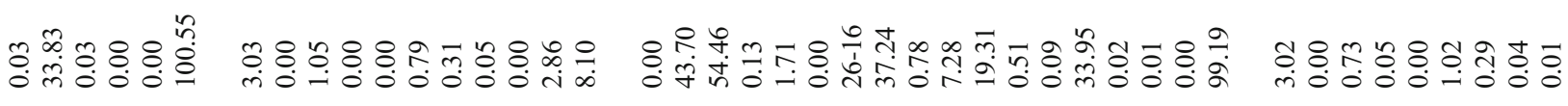

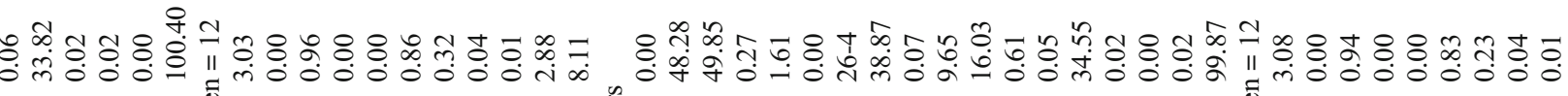

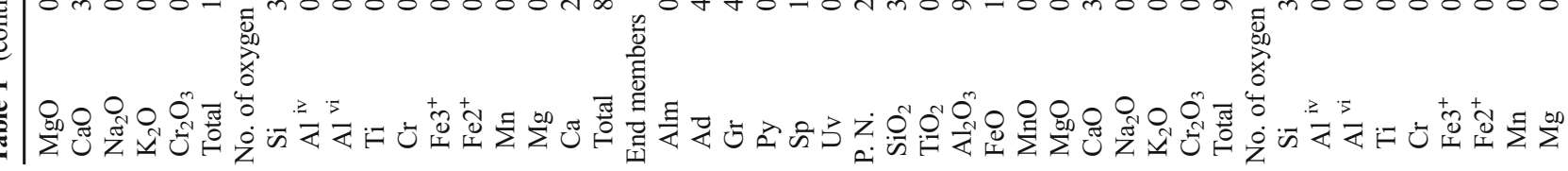




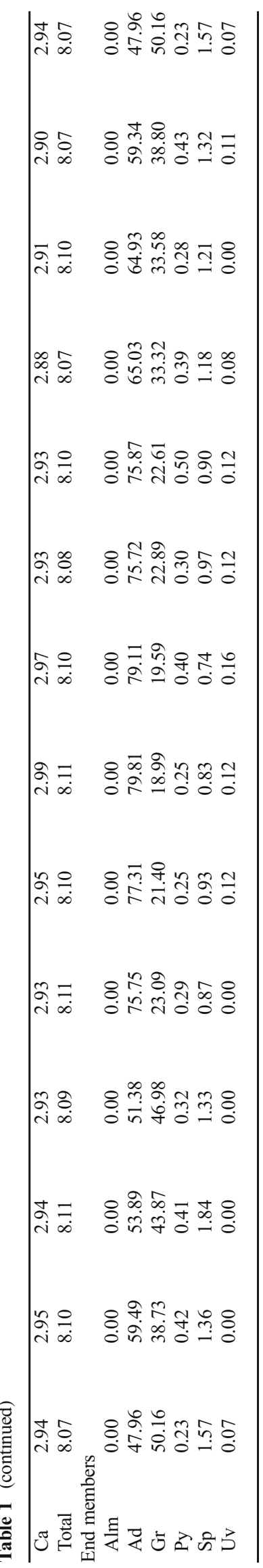

banded, disseminated, brecciated, vein-veinlets, replacement, and relict textures.

Magnetite typically occurs as massive, disseminated, and occasionally brecciated euhedral to subhedral crystals (Fig. 5a). Furthermore, magnetite presents as a matrix of garnet and pyroxene crystals in the garnet skarn and pyroxene skarn sub-zones (Figs. 3c, d and $4 c$, e). In some places, magnetite crystals altered to hematite along the crystal margins and fractures by the martitization process (Fig. 5b). Pyrite is the main sulfide mineral in the Qozlou Fe deposit. Pyrite typically occurs as subhedral to anhedral crystals with banded, disseminated, and veinveinlet textures. The banded form constitute from magnetite and sulfide minerals (mainly pyrite) alternation (Fig. 4d). There are some magnetite inclusions within the pyrite (Fig. 5c) indicating that pyrite formed after magnetite in the paragenetic sequence. Furthermore, pyrite veinlets crosscut the magnetite (Fig. 5d). Pyrite is rarely replaced by goethite.

Chalcopyrite has low abundances and occurs as disseminated and vein-veinlets of anhedral crystals (Fig. 5e). Chalcopyrite crystals were mainly formed around the pyrites. In some places, chalcopyrite is replaced by covellite (Fig. 5f). Pyrrhotite typically occurs as anhedral crystals which is restricted to the pyroxene skarn sub-zone. Pyrrhotite usually appears with pyrite and chalcopyrite in this sub-zone. Pyrrhotite has inclusions of pyrite (Fig. $5 \mathrm{~g}$ ), documenting that the pyrrhotite is a later phase than pyrite. Furthermore, chalcopyrite was formed around the pyrrhotite (Fig. 5h) indicating that chalcopyrite is a later phase than pyrrhotite. During the supergene processes, pyrite and magnetite are replaced by goethite and hematite, and chalcopyrite is replaced by covellite. Furthermore, goethite occurs as a fracture-filling form (Fig. 5i). Paragenetic sequence of minerals in the Qozlou Fe skarn deposit is shown in Fig. 6.

\section{Mineral chemistry}

\section{Garnet}

Totally, 41 points were analyzed on the garnet crystals. The EPMA analysis results, calculated cations, and endmember compositions of garnet crystals are given in Table 1. Most of the analyzed garnets are anisotropic and show clear zoning (Fig. 7a), while there are some isotropic garnets (Fig. 7b). In general, garnet crystals have andradite-grossularite compositions $\left(\mathrm{Ad}_{39.97-100}-\mathrm{Gr}_{0-}\right.$ 49.62) and isotropic garnets have a narrow compositional range along their marginal growth lines with andradite composition $\left(\mathrm{Ad}_{98.2-100}\right.$; Fig. $\left.7 \mathrm{c}\right)$. The garnets in the Qozlou Fe deposit are Fe-rich and have high $\mathrm{Fe} /(\mathrm{Fe}+\mathrm{Al})$ ratios (0.49-1; Fig. 7d). There is not any almandine component in the garnets; uvarovite and pyrope are negligible 
(between $0-0.24$ and $0-0.67$, respectively), and the spessartine component is minor (between 0 and 1.84) (Table 1). The chemical formula for garnets varies distinctively and is as follows:

$$
\begin{gathered}
\mathrm{Ca}(2.8-3.03) \mathrm{Mg}(0-0.02) \mathrm{Mn}(0.02-0.05) \mathrm{Fe}^{2+}(0.23-0.47) \\
\left.\mathrm{Fe}^{3+}{ }_{(0.71-1.64}\right) \mathrm{Al}(0-1.1) \mathrm{Ti}(0-0.08) \mathrm{Si}(2.96-3.14) \mathrm{O}_{12}
\end{gathered}
$$

There is a distinct compositional variation from the core to the rim of the most anisotropic garnet crystals. FeO contents increase and $\mathrm{Al}_{2} \mathrm{O}_{3}$ contents decrease from the core to the rim (Fig. 8a). Furthermore, specific differences are present in the andradite-grossularite component within the zoned garnet crystals (Fig. 8b). In the central parts of the zoned garnet crystals, andradite and grossular component have a similar ratio (Fig. 8b), while toward the rims of zoned garnets, andradite component increased, in which in some points it became pure andradite (Fig. 7c; Table 1). Very low content of $\mathrm{TiO}_{2}$ in the garnet crystals of the Qozlou Fe skarn implies a high activity of $\mathrm{SiO}_{2}$ during their formation (Dingwell and Brearley 1985). These low values are a clear difference between skarn garnets and igneous garnets (Huggins et al. 1977; Deer et al. 1992). For example, garnets of analcime-bearing syenitic bodies in the Kaleybar (Ashrafi et al. 2009), melanitebearing volcanic rocks of Alberta (Dingwell and Brearley 1985), garnets in the Rugged Mountain trachytic dykes of the Canadian Cordillera (Russell et al. 1999), garnets in the Kaiserstuhl phonolitic dykes of Germany (Armbruster et al. 1998), and garnets within the magmatic alkaline rocks from Finland and Kenya (Schingaro et al. 2016) all have relatively high $\mathrm{TiO}_{2}$ compared to skarn garnets. Some exceptions are present, including titanium-andradite $\left(\mathrm{TiO}_{2}=12.4 \%\right)$ from the skarns of Northern Red Sea Hill in Sudan (Huggins et al. 1977) and hydrothermal titanian andradite $\left(\mathrm{TiO}_{2}=2 \%\right)$ from Galore Creek in the Canadian Cordillera (Russell et al. 1999; Micko et al. 2014). The latter skarns are associated with alkali plutonic and volcanic rocks. Figure $7 \mathrm{~d}$ shows similarities and differences between garnets of the Qozlou skarn and the Pahnavar, Mission, Yerington, Bingham, Twin Butte, and Astamal skarn deposits (Harris and Einaudi 1982; Mokhtari 2012; Baghban et al. 2015, 2016).

Compositional variations of the garnet crystals from the Qozlou skarn are demonstrated on $\mathrm{Al}-\mathrm{Fe}^{3+}-\mathrm{Fe}^{2+}, \mathrm{Ca}-\mathrm{Fe}^{3+}-$ $\mathrm{Fe}^{2+}$ and $\mathrm{Al}-\mathrm{Ca}-\mathrm{Fe}$ triangular diagrams (Fig. 9). Garnets have high content of $\mathrm{Al}$ in the core, but they become rich in $\mathrm{Fe}^{3+}$ in the margins (Fig. 9a). Content of $\mathrm{Fe}^{2+}$ is nearly constant, and very small enrichment exists from the core to the rims. Based on the $\mathrm{Ca}-\mathrm{Fe}^{3+}-\mathrm{Fe}^{2+}$ triangular diagram (Fig. 9b), cores of garnets are rich in $\mathrm{Ca}$, while they show enrichment in $\mathrm{Fe}^{3+}$ toward the rims. On the $\mathrm{Al}-\mathrm{Ca}-\mathrm{Fe}$ triangular diagram (Fig. 9c), it is observed that $\mathrm{Ca}$ has almost constant content, while $\mathrm{Al}$ content decreases from the core to the rims.

\section{Clinopyroxene}

A total of 22 points were analyzed on clinopyroxene crystals. The EPMA analysis results, calculated cations, and endmember compositions of clinopyroxene crystals are given in Table 2. Clinopyroxenes totally do not have clear zoning (Fig. $10 \mathrm{a}, \mathrm{b})$, but they show composition variation from the core to the rim, in which diopside values are slightly decreased and hedenbergite values are slightly increased from the core to the rim (Fig. 11a). Based on the EPMA data, the clinopyroxenes demonstrate diopsidic (salite; $\mathrm{En}_{29.43-42.5}-\mathrm{Fs}_{14.31-20.99}$ $\mathrm{Wo}_{43.08-50.17}$ ) composition (Fig. 10c, d). The clinopyroxenes in the Qozlou $\mathrm{Fe}$ deposit are $\mathrm{Mg}$-rich and have low $\mathrm{Fe} /(\mathrm{Fe}+$ $\mathrm{Mg}$ ) ratios (0.31-0.41; Fig. 10e). The clinopyroxenes generally have low $\mathrm{TiO}_{2}, \mathrm{MnO}$, and $\mathrm{Cr}_{2} \mathrm{O}_{3}$ (Table 2). As shown in Fig. $11 \mathrm{~b}$, there are significantly lower contents of $\mathrm{Na}(0.01-$ 0.04 a.p.f.u) and $\mathrm{Al}(0.01-0.15$ a.p.f.u.) without any $\mathrm{Ti}$ and $\mathrm{Cr}$ (in a.p.f.u) indicating that the clinopyroxenes are of metamorphic origin. Figure 10e shows similarities and differences between clinopyroxenes of the Qozlou Fe skarn and clinopyroxenes from the Cananea, Yerington, Bingham, Twin Butte, Astamal, and Pahnavar skarn deposits (Harris and Einaudi 1982; Mokhtari 2012; Baghban et al. 2015, 2016). The chemical formula for clinopyroxene varies slightly and is as follows:

$$
\begin{aligned}
& \mathrm{Na}(0.01-0.14) \mathrm{Ca}(0.74-1.02) \mathrm{Mg}(0.55-0.79) \mathrm{Fe}^{2+}(0.22-0.42) \\
& \mathrm{Al}(0.01-0.15) \mathrm{Si}(1.93-2.07) \mathrm{O}_{6}
\end{aligned}
$$

The $\mathrm{Mn} / \mathrm{Fe}$ ratio of clinopyroxene varies according to the type of metal concentrated in the skarn deposit (Nakano et al. 1991). Most pyroxenes of $\mathrm{Cu}-\mathrm{Fe}$ skarn deposits are characterized by a low $\mathrm{Mn} / \mathrm{Fe}$ ratio $(<0.1)$, whereas those of $\mathrm{Pb}-\mathrm{Zn}$ deposits have a high $\mathrm{Mn} / \mathrm{Fe}$ ratio (Nakano et al. 1991). Clinopyroxene crystals of the Qozlou skarn have a negligible $\mathrm{Mn} / \mathrm{Fe}$ ratio, up to 0.03 .

\section{Skarnification process}

The mineralogy and chemical compositions of skarn minerals in skarn aureoles tend to be controlled by the chemical composition of the host rocks and associated intrusion, composition of the metasomatizing fluids, and $\mathrm{P}-\mathrm{T}$ conditions (Meinert et al. 2005). Most skarn deposits are characterized by two distinctly different alteration styles, which comprise an early stage with anhydrous minerals, such as garnet and pyroxene, and a retrograde alteration event with hydrous minerals, such as amphibole and epidote (Meinert et al. 2003); the latter is typically the ore-forming hydrothermal event (Zheng et al. 2015). The formation of skarns can be related to three main stages: (1) isochemical prograde thermal metamorphism 


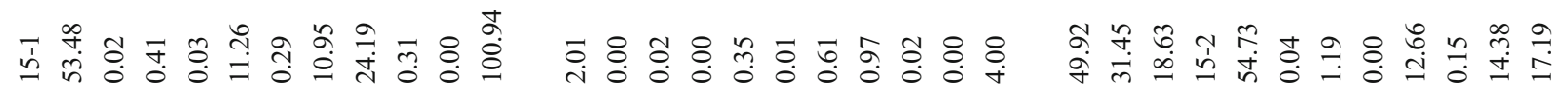

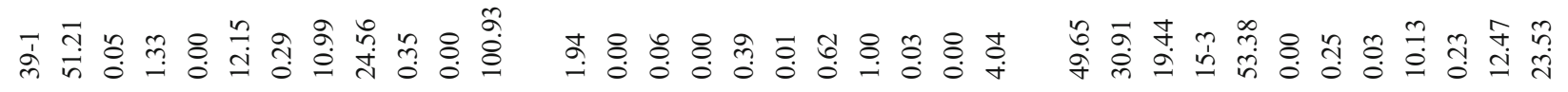

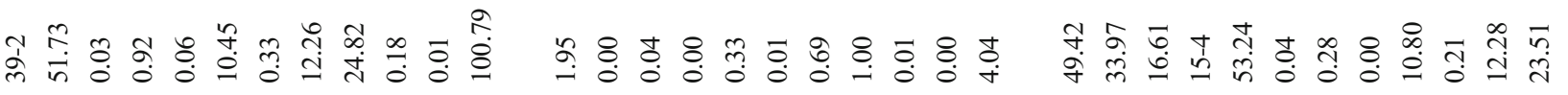

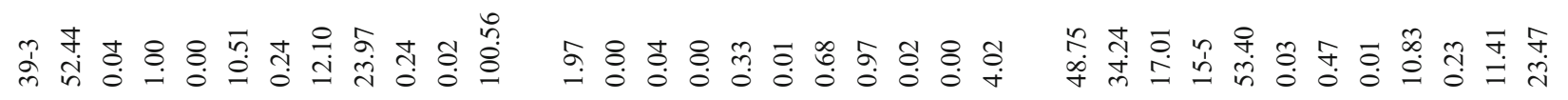

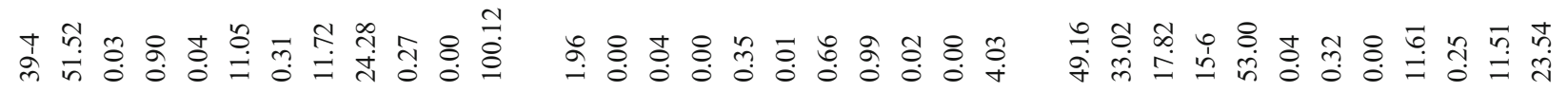

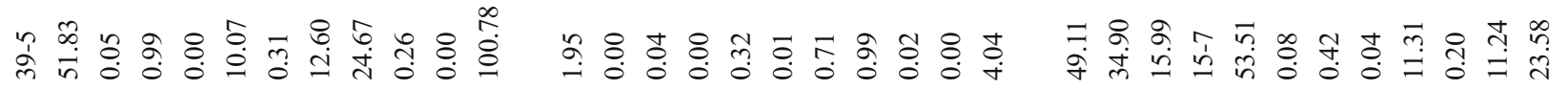


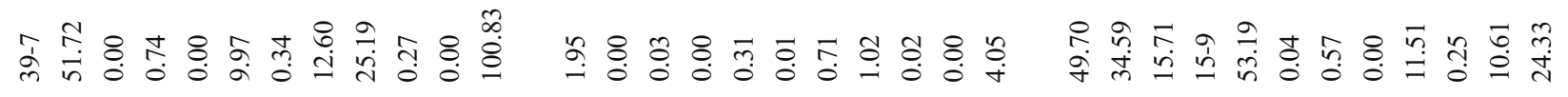

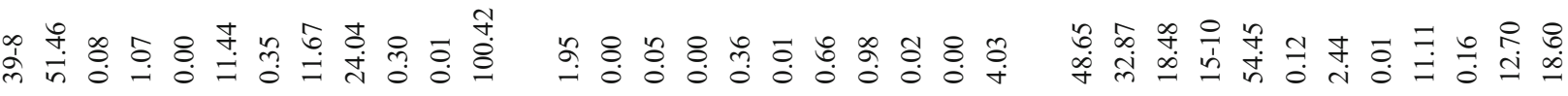

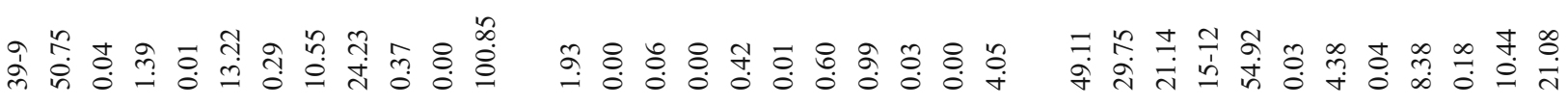
mे

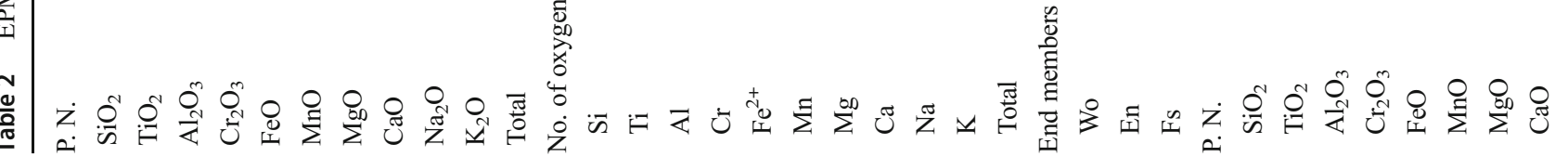




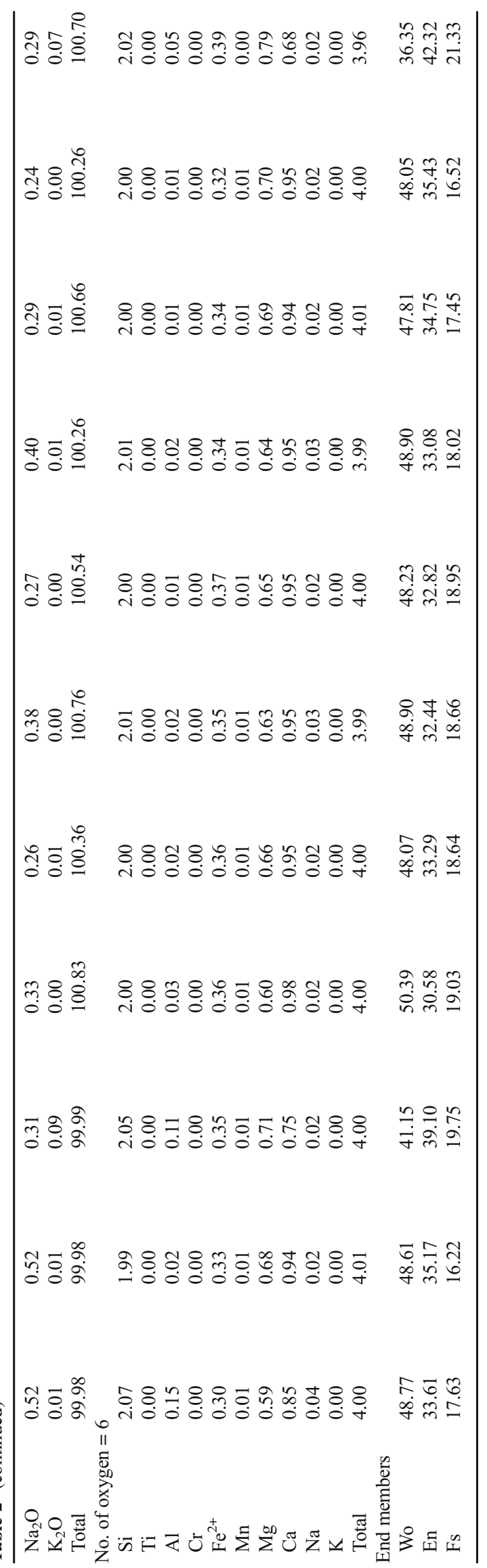

(metamorphic-bimetasomatic), (2) metasomatic prograde, and (3) retrograde hydrothermal alteration (Pirajno 2009).

Based upon field evidences along with mineralogical and petrographic data from the impure carbonate rocks (as protolith) and the skarn zone, the metamorphic-metasomatic zones in the Qozlou area can be classified as Fe-bearing calcic skarns.

\section{Metamorphic-bimetasomatic stage}

This sub-stage was coeval with the initial emplacement of the Qozlou granitic magma into the Upper Cretaceous impure carbonate rocks. The effect of heat flow from the intrusion caused the enclosing rocks to become isochemically marmorized (metamorphosed) in almost homogeneous limestone layers and bimetasomatized (skarnoid-hornfels) in intercalations of clay-rich carbonates. The metamorphic processes caused the micritic limestone to become recrystallized, developing equilibrium mosaic textures. However, in the clayrich intercalations, in addition to recrystallized calcites, a series of fine-grained, Fe-poor calc-silicates (clinopyroxene) were developed (skarnoid-hornfels; pyroxene-bearing marbles). No or negligible amounts of opaque minerals (oxides and/or sulfides) were formed during this stage.

\section{Prograde metasomatic stage}

Emplacement of magma and the start of crystallization are associated with the development of a volatile-rich phase (e.g., Meinert 1992; Candela and Piccoli 1995). The exsolution of a volatile phase from the magma and the partitioning of metals and chlorine between the melt and a volatile phase have been modeled by Burnham (1979), Cline and Bodnar (1991), Candela and Piccoli (1995), Shinohara and Kazahaya (1995), and Hedenquist et al. (1998).

This sub-stage commenced with the onset of consolidation and crystallization of the Qozlou granitic magma. During this process, the aqueous phase in the magma gradually became saturated and exsolved as a separate phase. As crystallization progressed, the volume of hydrothermal fluid generated and evolved, increased in the still-unconsolidated Qozlou intrusion. Penetration of exsolved fluids into the country rocks leads to transforming elements and suitable reactions. Bimetasomatic alteration was accompanied by decarbonation reactions that normally cause the formation of fractures in the carbonaceous host rock. This type of fracturing, along with those resulting from upward pressure exerted by the ascending magma, and the evolving fluid phase (hydro-fracturing), developed areas for the infiltration fluids into the metamorphic (marble)-bimetasomatic (skarnoid-hornfels) rocks. Evidence of the metasomatic alteration which occurred during this stage is provided by a series of medium to coarse-grained Fe-rich anhydrous calc-silicate minerals (grandite and salite; Figs. 7c 

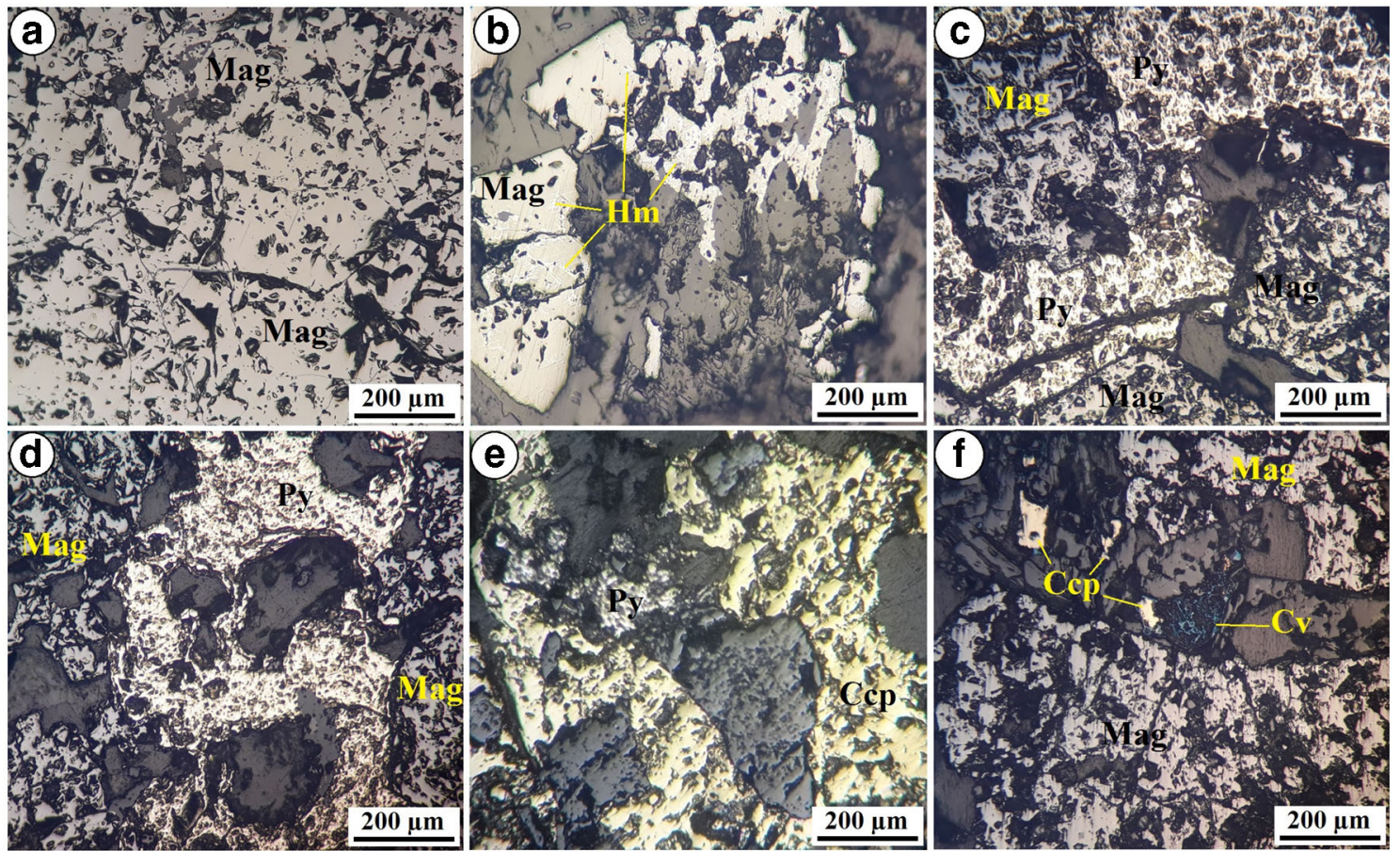
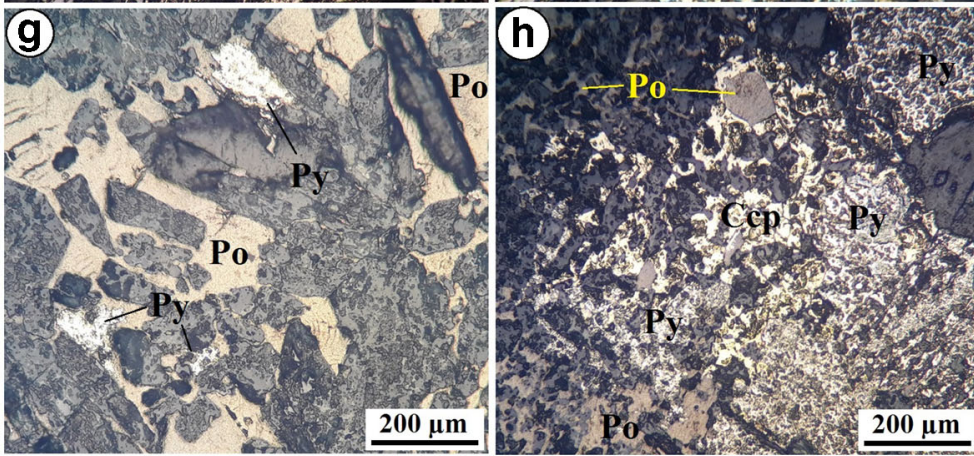

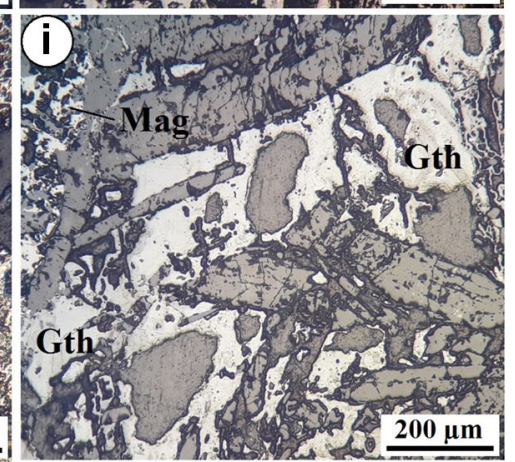

Fig. 5 a Massive anhedral magnetite; $\mathbf{b}$ disseminated magnetite replaced by hematite along the fractures and margins; $\mathbf{c}$ idiomorphic magnetite inclusion within pyrite; $\mathbf{d}$ pyrite veinlet crosscutting magnetite crystals; e irregular-shaped chalcopyrite around pyrite; $\mathbf{f}$ fine-grained chalcopyrite

and 10c). The replacement of voluminous amounts of marbles by grandite and salite may suggest strongly that substantial quantities of dissolved components such as $\mathrm{Fe}, \mathrm{SiO}_{2}$, and $\mathrm{Mg}$ were transferred into the skarn system by metasomatizing hydrothermal fluids. Garnets have high modal abundances against pyroxenes in the Qozlou skarn aureole. Although compositional variations of the batholith and protolith exert a strong control on the mineralogy of the skarns (e.g., Meinert 1995; Ray et al. 1995), the high garnet to pyroxene ratios may be related to the high oxidation state of the pluton and hydrothermal fluids (Meinert 1997).

\section{Retrograde metasomatic stage}

Petrographic studies indicate that retrograde stage in the study area is divided into two distinct but continuous sub-stages: (1) replaced by covellite; $\mathbf{g}$ pyrite inclusions within pyrrhotite; $\mathbf{h}$ inclusions of pyrrhotite within chalcopyrite; $\boldsymbol{i}$ fracture-filling goethite. Abbreviations as in Fig. 4

ore-forming sub-stage (early retrograde sub-stage) and (2) low-temperature sub-stage (late retrograde sub-stage).

Ore-forming sub-stage During this sub-stage, relatively low-temperature hydrothermal fluids and processes such as hydrolysis, carbonation, and sulfidation (e.g., Einaudi 1982a,b; Meinert 1995) led to anhydrous calc-silicate minerals which were formed during the prograde stage, and replaced by an assemblage of hydrous calc-silicate minerals (epidote and actinolite), oxides (magnetite), sulfides (pyrite, pyrrhotite, and chalcopyrite), and carbonates (calcite) mainly along the fractures. During this sub-stage, garnet has been replaced by epidote, magnetite, calcite, and quartz, and clinopyroxene has been replaced by actinolite, calcite, and opaque minerals. Epidote is the most common alteration mineral. A local increase in $f \mathrm{O}_{2}$ may have played an important role in the formation of epidote 
Fig. 6 The paragenetic sequence of ore and gangue minerals in the Qozlou Fe deposit

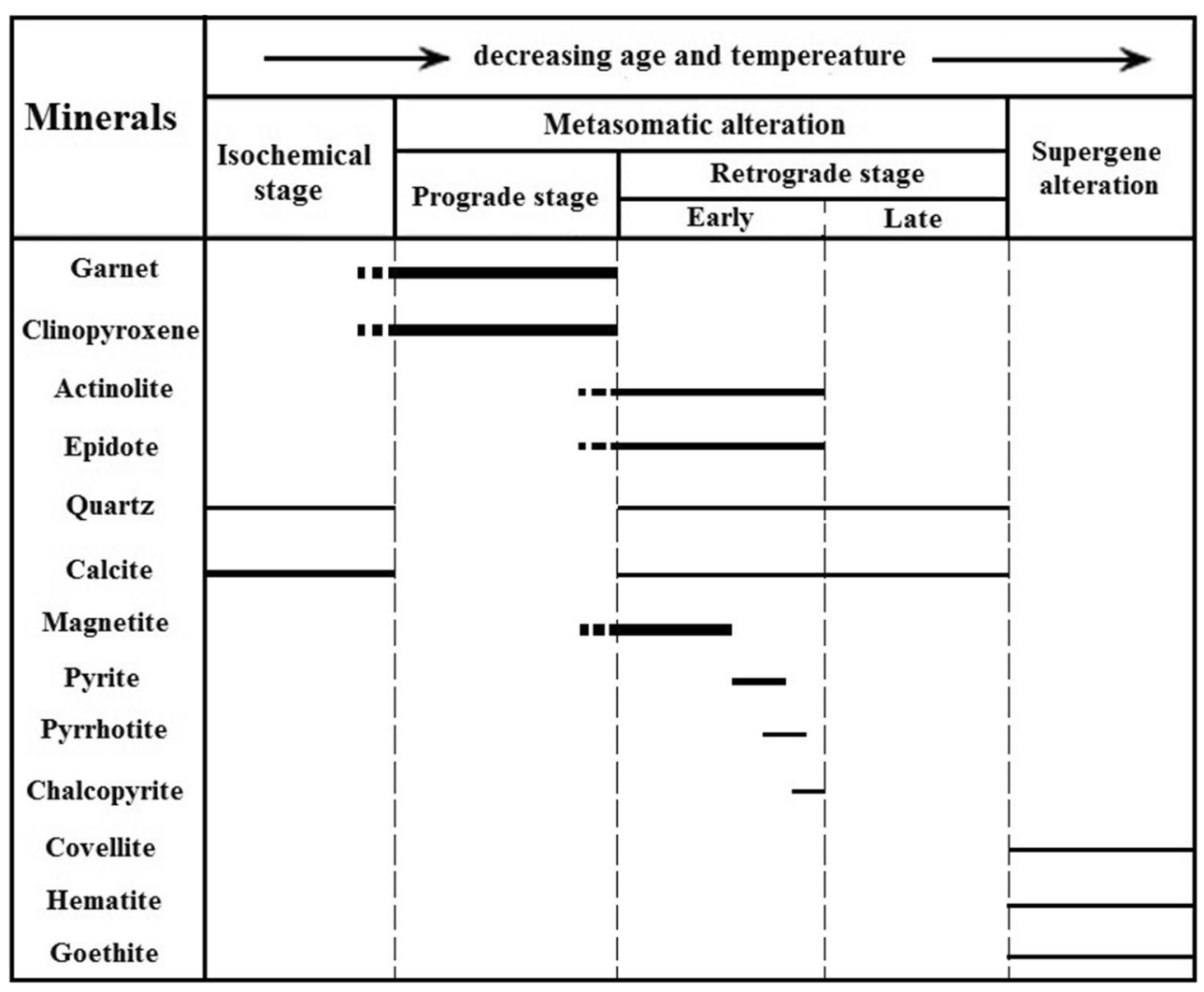

(Berman et al. 1985; Perkins et al. 1986) according to the following reaction:

$$
\begin{aligned}
& \mathrm{Ca}_{3}(\mathrm{Fe}, \mathrm{Al})_{2} \mathrm{Si}_{3} \mathrm{O}_{12}+5 / 4 \mathrm{O}_{2}+\mathrm{HCO}_{3}{ }^{-} \\
& \quad=\mathrm{CaCO}_{3}+\mathrm{Ca}_{2} \mathrm{FeAl}_{2} \mathrm{Si}_{3} \mathrm{O}_{12}(\mathrm{OH})+0.5 \mathrm{Fe}_{2} \mathrm{O}_{3}
\end{aligned}
$$

Einaudi (1982a) proposed that garnet can be replaced by quartz + calcite + magnetite during the early retrograde substage (ore-forming sub-stage):

$$
\begin{aligned}
3 \mathrm{Ca}_{3} \mathrm{Fe}_{2} \mathrm{Si}_{3} \mathrm{O}_{12}+3 \mathrm{HCO}_{3}{ }^{-}+15 \mathrm{H}^{+} \\
=3 \mathrm{CaCO}_{3}+9 \mathrm{SiO}_{2}+2 \mathrm{Fe}_{3} \mathrm{O}_{4}+6 \mathrm{Ca}^{2+}+9 \mathrm{H}_{2} \mathrm{O} \\
\quad+0.5 \mathrm{O}_{2}
\end{aligned}
$$

Actinolite in this sub-stage was probably formed by retrograde alteration of clinopyroxene (Deer et al. 1992):

$$
\begin{aligned}
& 5 \mathrm{Ca}(\mathrm{Mg}, \mathrm{Fe}) \mathrm{Si}_{2} \mathrm{O}_{6}+\mathrm{H}_{2} \mathrm{O}+3 \mathrm{CO}_{2} \\
& \quad=\mathrm{Ca}_{2}(\mathrm{Mg}, \mathrm{Fe})_{5} \mathrm{Si}_{8} \mathrm{O}_{22}(\mathrm{OH})_{2}+3 \mathrm{CaCO}_{3}+2 \mathrm{SiO}_{2}
\end{aligned}
$$

Presence of small magnetite crystals within the garnet and clinopyroxenes along with epidote, actinolite, calcite, and quartz in the Qozlou Fe skarn deposit demonstrates that magnetite was formed after garnet and clinopyroxene during the early retrograde sub-stage. Furthermore, presence of magnetite between garnet and clinopyroxenes (Figs. 3c, d and 4c, e) suggests that magnetite was formed later than garnet and pyroxene. Crosscutting of magnetite by sulfide veinlets (pyrite and chalcopyrite; Fig. 5d) and presence of magnetite inclusions within the pyrite (Fig. 5c) demonstrate that sulfides were formed later than magnetite.

Low-temperature sub-stage In this sub-stage, due to the influx of low-temperature hydrothermal fluids, both anhydrous and hydrous calc-silicates which had developed during earlier stages were altered to fine-grained aggregates of clay minerals, chlorite, calcite, quartz, and hematite. Released $\mathrm{Ca}$ and Si from calc-silicate minerals present as late quartz and calcite vein-veinlets (Fig. 4e).

\section{Physico-chemical condition of Skarn formation}

The prograde metasomatic processes probably began after metamorphic and bimetasomatic processes occurred by infiltration of hot hydrothermal fluids from the intrusion, trough fractures to the marble, and skarnoid zones. The fluids contained $\mathrm{Fe}, \mathrm{Si}$, and $\mathrm{Mg}$ and were under oxidizing conditions, causing decarbonation reactions and the development of Fe-rich, anhydrous calc-silicates such as garnet and pyroxene. Various data indicate that the $\mathrm{XCO}_{2}$ in hydrothermal fluids involved in some calcic skarns related to porphyry copper stocks (as an open system) is generally quite low (0.1; Einaudi 1982a; Taylor and O'Neil 
Fig. 7 a, b The BSE images from zoned (a) and without zoning (b) garnet crystals in sample Q-26 from the Qozlou Fe deposit; the EPMA-analyzed points are shown on the photos; $\mathbf{c}$ composition of the garnet crystals from the Qozlou Fe skarn deposit on the Ad-Gr-(Sp + Al + Pyp) ternary diagram; representative EPMA data are given in Table 1; d comparison of the $\mathrm{Fe} /(\mathrm{Fe}+\mathrm{Al})$ mole fraction of garnet from the Qozlou skarn and some other skarn deposits. Adopted data from Einaudi (1982a), Pahnavar data from Mokhtari (2012), Yerington data from Harris and Einaudi (1982), Astamal, Bingham, Mission, and Twin Butte data from Baghban et al. (2015)

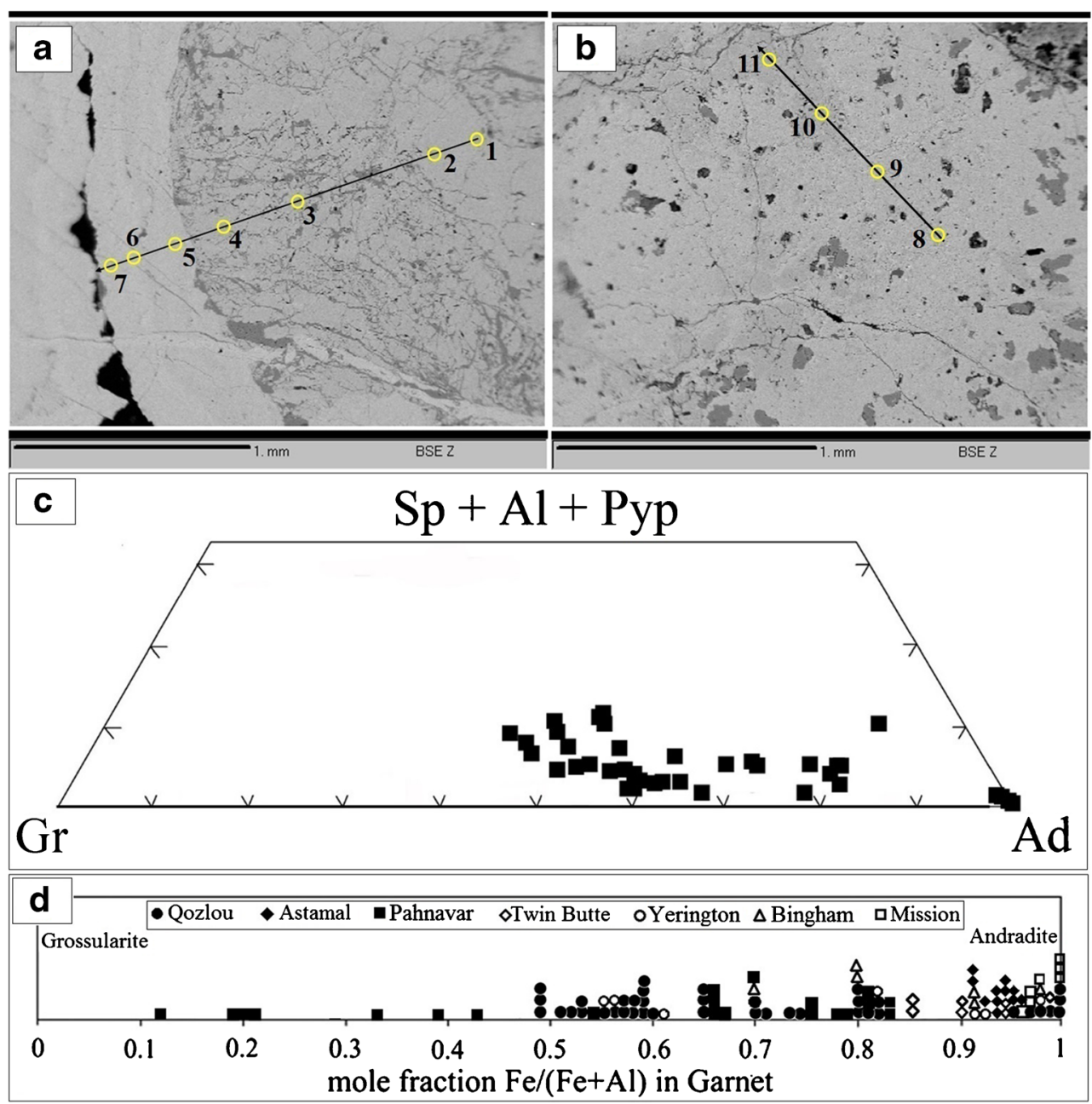

1977). Furthermore, Einaudi et al. (1981) believed that in most skarns, $\mathrm{XCO}_{2}$ varies from initial values of 0.2 to later values of 0.05 . However, these values can be slightly higher when wollastonite is present. Andradite is stable in relatively low $\mathrm{XCO}_{2}$ conditions, but its decomposition to hedenbergite, calcite, and magnetite and the later decomposition of hedenbergite to actinolite, calcite, and quartz is concomitant with increasing $\mathrm{XCO}_{2}$ (Uchida 1983). In this base, $\mathrm{XCO}_{2}$ values for Qozlou skarn deposit are considered less than 0.2 .
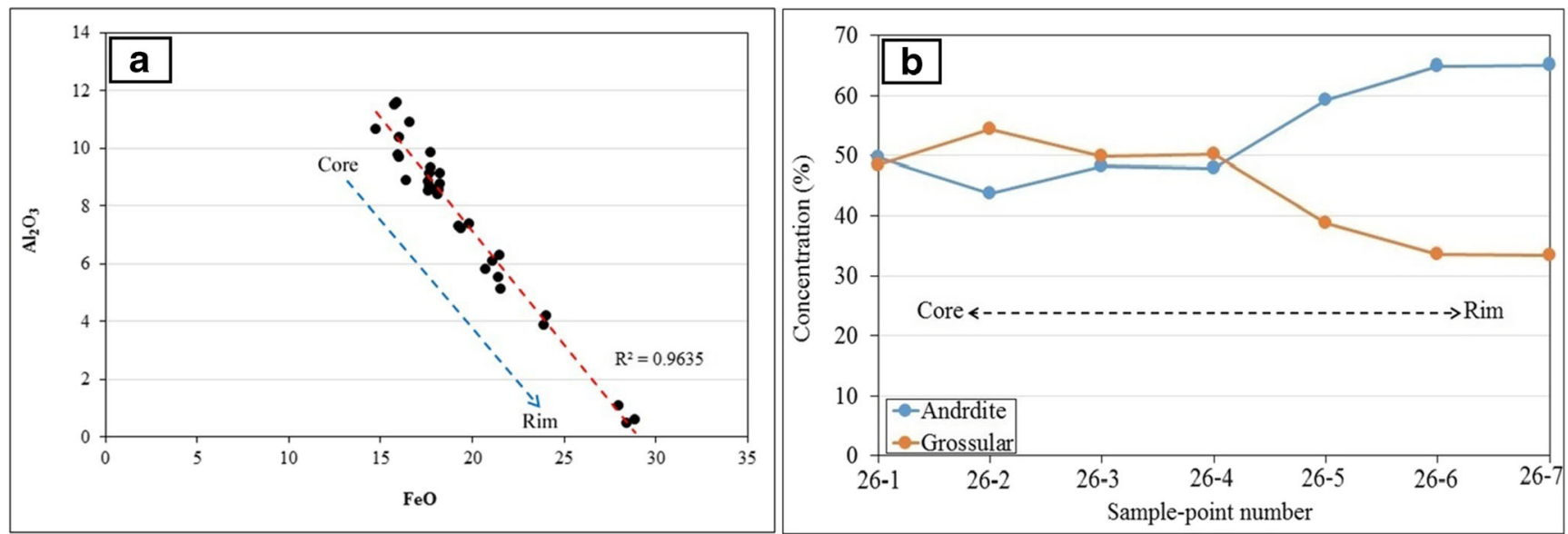

Fig. 8 a Compositional variations $\left(\mathrm{FeO}-\mathrm{Al}_{2} \mathrm{O}_{3}\right)$ from core to the rims of the garnet crystals in the Qozlou Fe skarn deposit; $\mathbf{b}$ compositional variation (andradite and grossularite) from core to the rim in one of the zoned garnet crystals (Fig. 7a) from the Qozlou Fe skarn deposit 

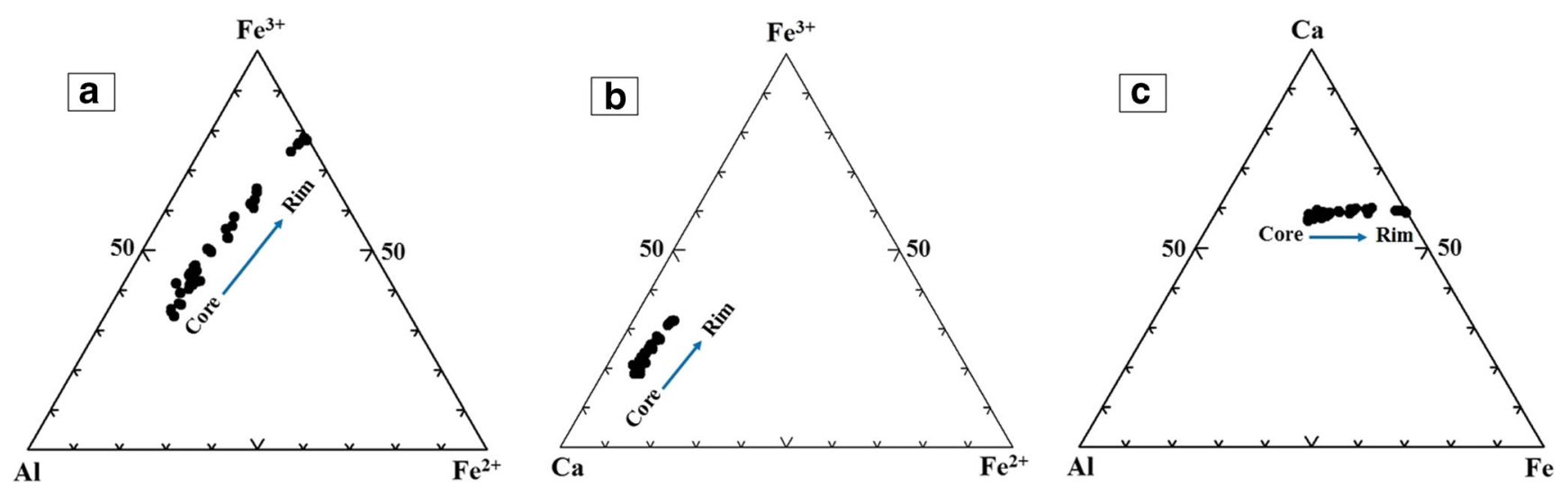

Fig. 9 Compositional variations of garnet crystals in the Qozlou Fe skarn deposit; a $\mathrm{Al}-\mathrm{Fe} 3^{+}-\mathrm{Fe}^{2+}$ triangular diagram; $\mathbf{b} \mathrm{Ca}-\mathrm{Fe}{ }^{3+}-\mathrm{Fe}^{2+}$ triangular diagram; c Al-Ca-Fe triangular diagram

For estimating physico-chemical conditions of skarnification processes in the Qozlou skarn, diagrams such as XCO vs. temperature, $\log f \mathrm{O}_{2}$ vs. temperature, and $\log$ $f \mathrm{~S}_{2}$ vs. $\log f \mathrm{O}_{2}$ were used (Sweeney 1980; Einaudi 1982a; Meinert 1995). EPMA data show that the compositional variation of garnets at Qozlou is $\mathrm{Ad}_{39.9-100} \mathrm{Grs}_{0-49.62}$. Thus, based on the $\mathrm{T}-\mathrm{XCO}_{2}$ diagram (Sweeney 1980; Fig. 12a), garnets are believed to have been formed at temperatures between 510 and $460{ }^{\circ} \mathrm{C}$. Furthermore, the absence of wollastonite in the Qozlou skarn may suggest that the prograde skarn event took place at temperatures less than $550^{\circ} \mathrm{C}$, at 500 bar fluid pressure, and $\mathrm{XCO}_{2}=0.1$ (Fig. 12b). Replacement of andradite by a magnetite + calcite + quartz assemblage occurred at temperatures of $\sim 430{ }^{\circ} \mathrm{C}$ (Fig. 12b). The presence of inter-growth textures and non-replacive crystal boundaries between garnets and clinopyroxenes suggests that they formed contemporaneously, in $430-550^{\circ} \mathrm{C}$ and $f \mathrm{O}_{2}$ between $10^{-26}$ and $10^{-23}$ (Fig. $12 b)$.

Chavideh et al. (2018) believed that the formation of pure andradite garnets is related to hot hydrothermal fluids in the Qazan skarn (Central Iran) that caused oxidation of the remained fluid with the rise of the $\mathrm{Fe}^{3+} / \mathrm{Al}$ ratio, increase of $f \mathrm{O}_{2}$, and finally high concentration of andradite component in the garnet solid solution. Garnets which are formed far from these conditions have more grossularite component. At these times, $f \mathrm{O}_{2}$ is lower resulting in low concentration of $\mathrm{Fe}^{3+}$ in fluid (Gaspar et al. 2008). According to the composition of garnets in the Qozlou skarn, it can be concluded that $f \mathrm{O}_{2}$ was mainly high during the garnet formation, especially during the formation of pure andradite garnets.

Garnet growth reflects the interplay of heating and fluid infiltration into the host rocks (e.g., Jamtveit 1997; Meinert et al. 2005). Coarse-grained garnets in skarn deposits are usually formed in the periphery of the associated intrusive bodies. However, Einaudi et al. (1981) suggested that dimensions of garnet grains are more associated with fluid flow rate and the equilibrium condition between fluid flow and wall-rock. Relatively high rates of fluid flow result in supersaturation of elements such as $\mathrm{Fe}, \mathrm{Mg}, \mathrm{Al}$, and $\mathrm{Ca}$. In the magmatic hydrothermal environments situated distal to the intrusive bodies, fluid movement is relatively limited and consequently the degree of super-saturation is limited. In such conditions, crystals grow slowly and form fine-grained crystals. Presence of coarse-grained euhedral garnet crystals in the Qozlou Fe skarn deposit (Fig. 4c, d) can be attributed to the proximity of skarn aureole to the intrusion and high fluid flow rate.

Fluids that equilibrated with intrusion may have been in equilibrium with anhydrous calc-silicate assemblages up to temperatures around $430{ }^{\circ} \mathrm{C}$, and probably, retrograde alteration started at temperatures less than $430{ }^{\circ} \mathrm{C}$ (Fig. 12c). With decreasing temperatures and increasing $f \mathrm{O}_{2}$, garnet was altered to epidote, quartz, pyrite, and carbonate assemblages, and clinopyroxene to tremolite-actinolite, quartz, pyrite, and calcite. At this stage, fluids equilibrated with the newly formed assemblages, with $\mathrm{XCO}_{2}=0.1$ (Harris and Einaudi 1982a). At temperatures $>430{ }^{\circ} \mathrm{C}$, even at a high sulfidation state, andradite is stable (Einaudi 1982a). However, at temperatures $<430^{\circ} \mathrm{C}$, the fluids equilibrated with intrusion and with a relatively high sulfur fugacity $\left(f \mathrm{~S}_{2}<10^{-6}\right)$ and were not in equilibrium with andradite. This gave place to alteration assemblages of quartz, calcite, and pyrite (Fig. 12c). With decreasing $f \mathrm{~S}_{2}\left(\approx 10^{-6}\right)$, such fluids could form assemblages of magnetite (Fig. 12d). Therefore, it can be deduced that the retrograde metasomatizing fluids had $f \mathrm{~S}_{2}=10^{-6.5}$ and temperatures $<430{ }^{\circ} \mathrm{C}$ in the Qozlou Fe skarn deposit (Fig. 12c, d). The development of low-temperature hydrothermal assemblages of chlorite, clay minerals, subordinate hematite, and calcite after the early formed assemblages may suggest that the late metasomatizing fluids (late retrograde sub-stage) were probably under higher oxidizing conditions. In fact, at relatively low temperatures $\left(<300{ }^{\circ} \mathrm{C}\right)$, waters of meteoric origin that were probably introduced into the skarn system caused decreasing $\mathrm{pH}$ and increasing activity of sulfate (Einaudi and Burt 1982).

Heimann et al. (2009) believed that garnet composition is an indicator for fluid source during skarnification processes. 


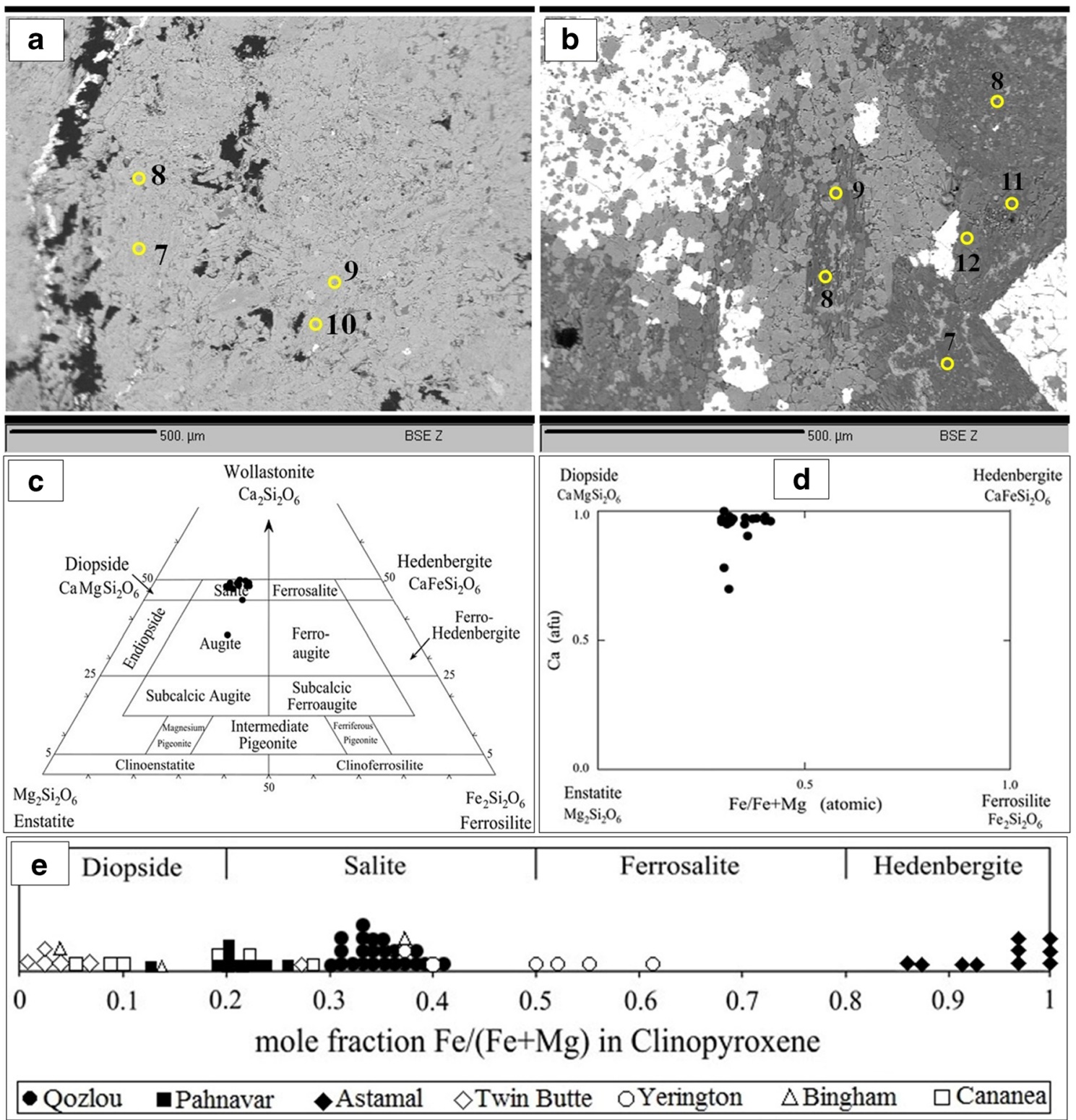

Fig. 10 a, b The BSE images from clinopyroxene crystals (a from sample Q-39 and $\mathbf{b}$ from sample Q-15) from the Qozlou Fe deposit. The EPMAanalyzed points are shown on the photos; c composition of the clinopyroxene crystals from the Qozlou Fe skarn deposit on the ferrosilite-enstatite-wollastonite ternary diagram (Deer et al. 1992). Representative EPMA data are given in Table $1 ; \mathbf{d ~ C a}$ (afu) vs. $\mathrm{Fe} /(\mathrm{Fe}+$ $\mathrm{Mg}$ ) (atomic) for clinopyroxenes in the Qozlou Fe skarn deposit (after

They proposed the $\mathrm{Fe} / \mathrm{Ti}$ vs. $\mathrm{Al} /(\mathrm{Al}+\mathrm{Fe}+\mathrm{Mn})$ diagram for recognition of the fluid source. Based on this diagram, most of the garnets of the Qozlou skarn were formed from mixed magmatic-hydrothermal fluids (30-80\% magmatic fluid), while pure andradite garnets were formed by mainly hydrothermal fluids (Fig. 13a). Furthermore, Clechenko and Valley (2003) believed that garnets with a high $\mathrm{Fe}^{3+} / \mathrm{Al}$ ratio have high ${ }^{18} \mathrm{O}$ values, while garnets with a low $\mathrm{Fe}^{3+} / \mathrm{Al}$ ratio have low ${ }^{18} \mathrm{O}$ values. In this base, pure andradite garnets in the Qozlou skarn were formed from hydrothermal fluids of
Papike et al. 1998). Representative EPMA data are given in Table 1; e comparison of the $\mathrm{Fe} /(\mathrm{Fe}+\mathrm{Mg})$ mole fraction of clinopyroxenes from the Qozlou skarn and some other skarn deposits. Adopted data from Einaudi (1982a), Pahnavar data from Mokhtari (2012), Cananea data from Meinert (1992), Yerington data from Harris and Einaudi (1982), Astamal, Bingham, and Twin Butte data from Baghban et al. (2015)

meteoric origin and garnets with andradite-grossularite solid solution composition $\left(\mathrm{Ad}_{19-54}\right)$ originated from mixed magmatic-hydrothermal fluids.

\section{Skarn type}

The composition of garnet and pyroxene end members can be used as indicator for ore mineralization type in skarn deposit. Based on the EPMA data of garnet and pyroxenes from the Yemanquan $\mathrm{Fe}-\mathrm{Cu}-\mathrm{Zn}$ skarn deposit, Zuo et al. (2015) 

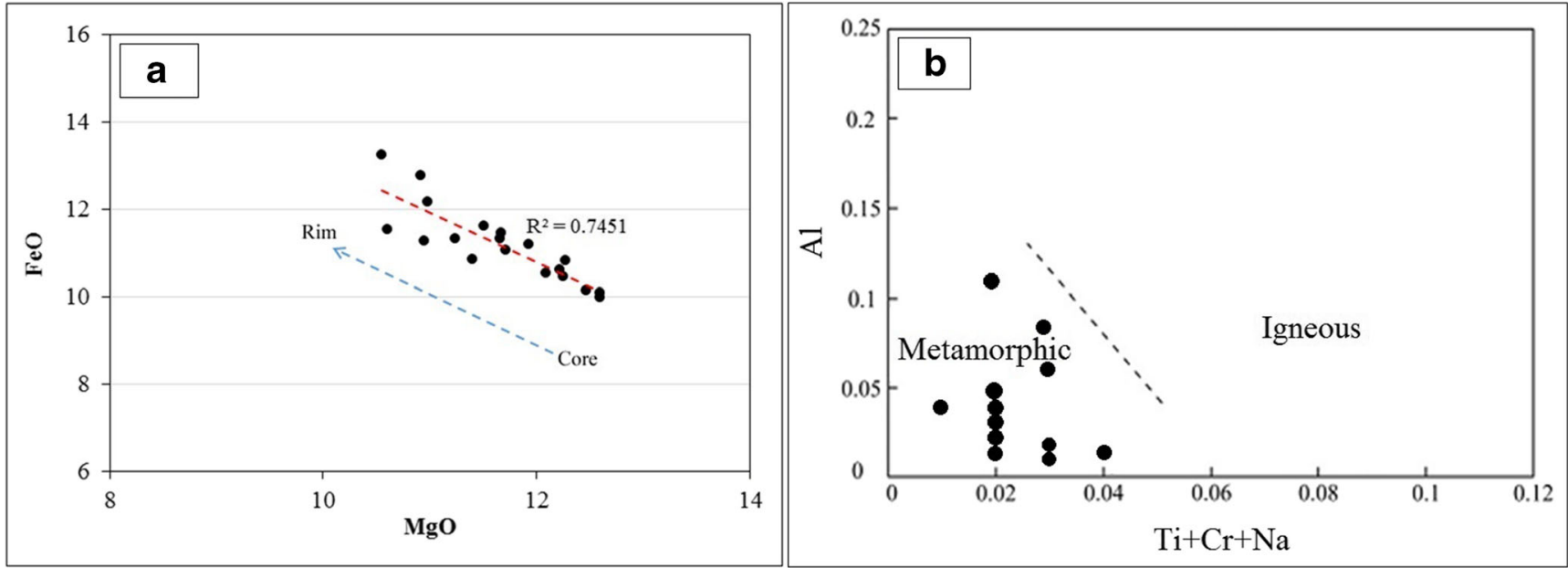

Fig. 11 a Compositional variations $(\mathrm{FeO}-\mathrm{MgO})$ from core to rim of the clinopyroxene crystals in the Qozlou $\mathrm{Fe}$ skarn deposit; $\mathbf{b} \mathrm{Al}$ vs. $(\mathrm{Ti}+\mathrm{Cr}+\mathrm{Na})$ diagram (Berger et al. 2005) displaying metamorphic genesis for clinopyroxene crystals from the Qozlou Fe skarn

proposed three areas on the pyroxene triangular diagram (Fig. 13b) and two areas on the garnet triangular diagram (Fig. 13c) which are demonstrating the ore mineralization type. Based on these diagrams, garnet and pyroxenes of the Qozlou skarn plot within type II area which is indicating for Fe skarn deposits (Fig. 13c, d).

\section{Conclusions}

The Qozlou deposit is a calcic Fe skarn that formed due to the intrusion of Qozlou porphyritic granite into the Upper Cretaceous carbonaceous rocks. Ore-forming fluids separated from the Qozlou intrusion and replaced the carbonaceous rocks precipitating calc-silicate minerals and ore minerals within the host rock. The most abundant calc-silicate minerals include garnet and clinopyroxene. Based on the EPMA data, garnets mainly have andradite-grossularite solid solution composition $\left(\operatorname{Ad}_{19-54}\right)$. Moreover, there are pure andradite garnets $\left(\operatorname{Ad}_{93.5-99.9}\right)$ in this skarn deposit. Garnet crystals mainly show distinct zonation. The oscillatory zoned garnets demonstrate compositional variations in which the cores have andradite-grossularite solid solution, while the rims have more enriched andradite component. Clinopyroxenes almost have diopsidic (salite) composition $\left(\mathrm{Di}_{58-70}\right)$ and they did not show typical zonation. The compositions of garnet and pyroxene end members indicate that Qozlou skarn can be classified as Fe skarn deposit.

Skarnification processes and their evolutionary trend can be categorized into three discrete stages including (1) isochemical (metamorphic-bimetasomatic), (2) metasomatic prograde, and (3) metasomatic retrograde. The prograde stage commenced shortly after the intrusion of the granitic magmas into impure carbonate rocks. The alteration progressed isochemically by the effects of heat flow from the pluton into the surrounding carbonaceous rocks. The pure carbonate rocks recrystallized forming calcic marble, and the impure carbonate layers were bimetasomatized giving place to skarnoid. Some anhydrous calc-silicates were developed by bimetasomatic processes from clay-rich carbonate interlayers during this stage. The development of these calc-silicates was accompanied by decarbonation reactions which caused a volume decrease and the subsequent formation of fractures in the rocks. The consolidation and crystallization of the granitic magma caused a high-temperature aqueous phase to be exsolved. Infiltration of such fluids through fractures resulted in $\mathrm{Fe}, \mathrm{Si}$, and $\mathrm{Mg}$ to be supplied to the marmorized and skarnoid zones. The introduction of these elements caused the formation of coarse-grained, anhydrous Fe-rich calc-silicates. Garnets formed during this stage were mainly andradite-grossularite solid solution in composition, and clinopyroxenes have diopsidic (salite) composition. Magnetite, pyrite, pyrrhotite, and chalcopyrite were formed during retrograde metasomatic stage (ore-forming sub-stage).

The lack of wollastonite as well as lack of replacement textures between clinopyroxene and garnet suggests temperature and $\mathrm{fO}_{2}$ conditions ranged between $430-550{ }^{\circ} \mathrm{C}$ and $10^{-26}-10^{-23}$ respectively, for the metasomatic prograde stage. During the ore-forming sub-stage (early retrograde), the prograde metasomatic alteration zones were affected by multiple episodes of hydro-fracturing, resulting in numerous channels for the infiltrating hydrothermal fluids. While the temperature remained $>460{ }^{\circ} \mathrm{C}$, the calc-silicates were stable. However, at temperatures $<430{ }^{\circ} \mathrm{C}$, fluids were not in equilibrium with anhydrous calc-silicates and retrograde alteration took place. During this stage, $\mathrm{Fe}$ and $\mathrm{Cu}$ along with $\mathrm{H}_{2} \mathrm{~S}$ and $\mathrm{CO}_{2}$ were also added to the skarn system, triggering hydrolysis, sulfidation, and carbonation reactions within the anhydrous calc-silicates. As a result, hydrous calc-silicates (epidote and actinolite), oxides (magnetite), sulfides (pyrite, pyrrhotite, and 

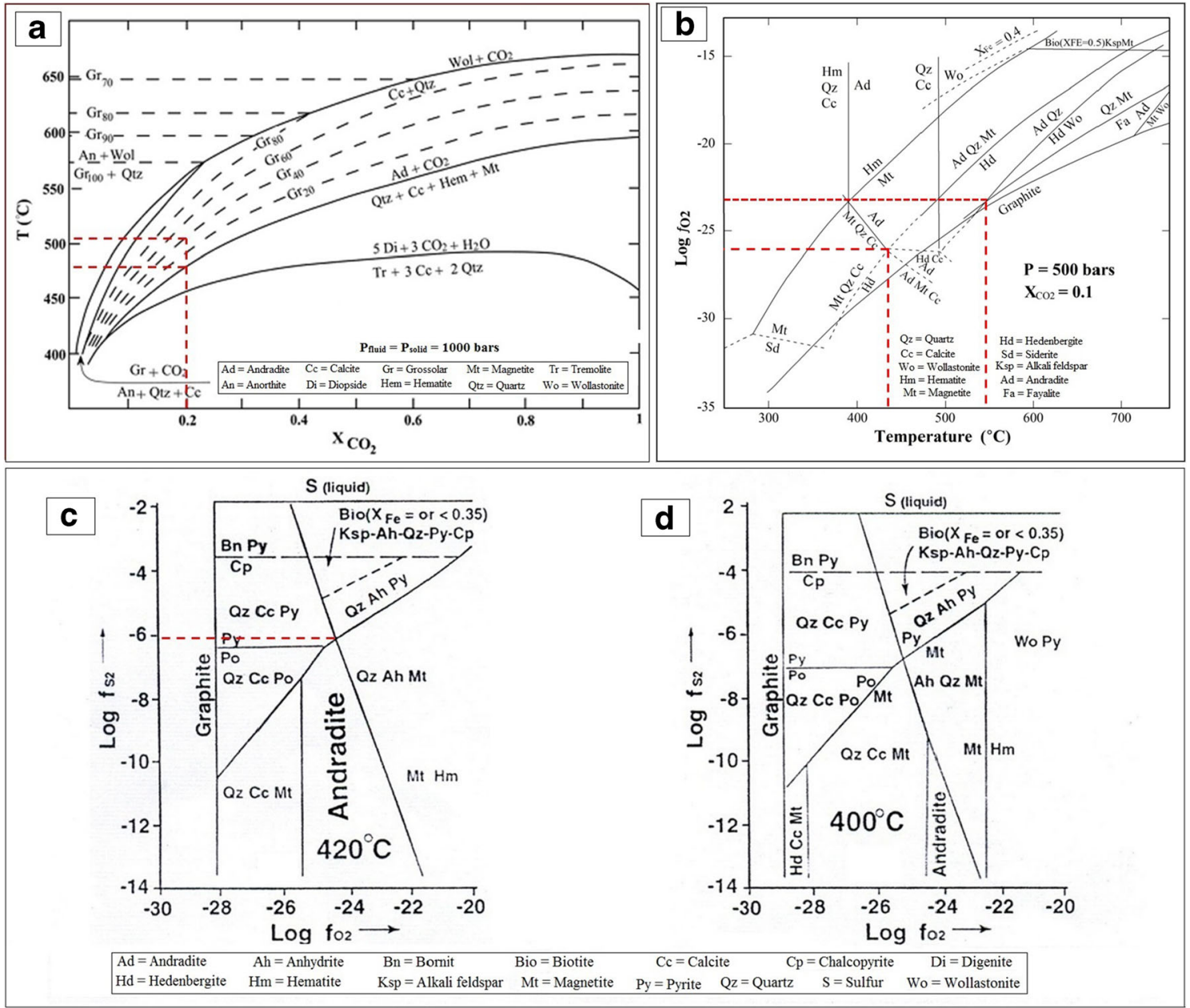

Fig. 12 a T- $\mathrm{XCO}_{2}$ diagram in $P_{\text {fluid }}=1000$ bars (adapted from Sweeney 1980). $\mathrm{Gr}_{100}$ is pure $\mathrm{Ca}-\mathrm{Al}$ garnet (grossular), Ad is pure $\mathrm{Ca}-\mathrm{Fe}$ garnet (andradite), and $\mathrm{Gr}_{20}-\mathrm{Gr}_{80}$ is andradite-grossularite solid solution; b a bivariate diagram of $\log f \mathrm{O}_{2}$ vs. temperature at 500 bar fluid pressure and $\mathrm{XCO}_{2}=0.1$ for the system $\mathrm{Ca}-\mathrm{Fe}-\mathrm{Si}-\mathrm{C}-\mathrm{O}-\mathrm{H}$ (Einaudi 1982a). Solid lines calc-silicates equilibria are based on experimental data from Greenwood (1967), Liou (1974), Gustafson (1974), and Taylor and Liou (1978); dashed lines are approximate locations of equilibria lacking experimental control; oxide buffers hematite-magnetite, quartz-magnetite-fayalite, and graphite are based on data from French and Eugster (1965) and French (1971). The siderite field is schematic, based on the lack of siderite-hedenbergite and siderite-andradite assemblages in skarns (Burt 1972). Biotite compositions in mole fraction annite for assemblage biotite-K feldspar-magnetite (hematite) from Wones and Eugster (1965); c, d bivariate diagrams of $\log f \mathrm{~S}_{2}$ vs. $\log f \mathrm{O}_{2}$ for andradite stability field between 420 and $400{ }^{\circ} \mathrm{C}$ at $\mathrm{XCO}_{2}=0.1$; calc-silicate and biotite equilibria are based on Liou (1974), Gustafson (1974), and Taylor and Liou (1978); $\mathrm{Cu}-\mathrm{Fe}-\mathrm{S}-\mathrm{O}-\mathrm{C}-\mathrm{H}$ equilibria are based on French and Eugster (1965), Barton and Skinner (1967), Scott and Barnes (1971), and Helgeson (1969); anhydrite equilibria are based on data from Robie et al. (1968)
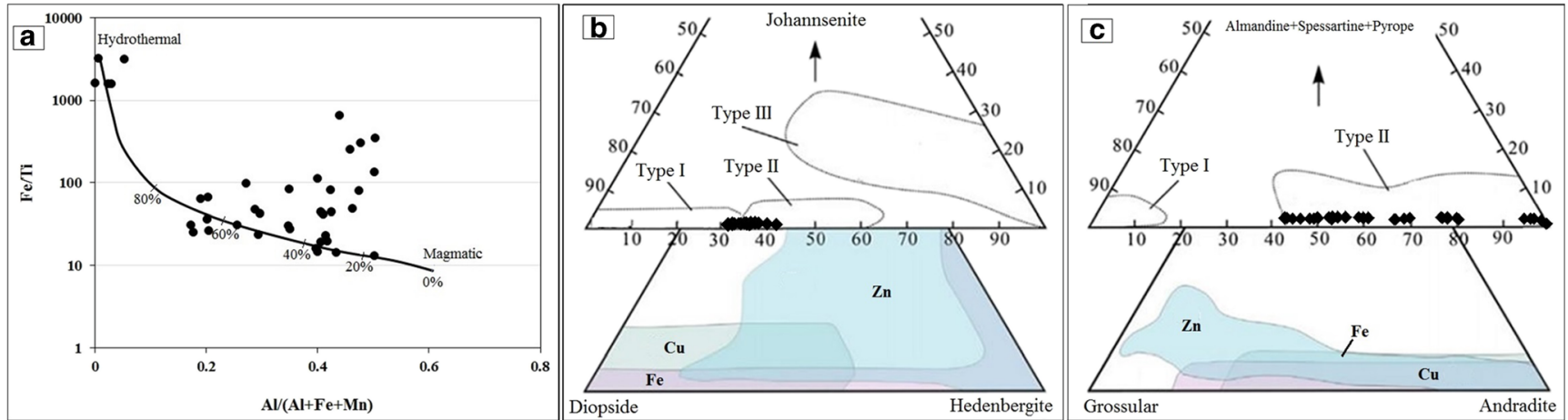

Fig. 13 a The ratio of magmatic and hydrothermal fluids involved in formation of the Qozlou skarn based on the $\mathrm{Fe} / \mathrm{Ti}$ vs. $\mathrm{Al} /(\mathrm{Al}+\mathrm{Fe}+$ Mn) diagram (Heimann et al. 2009); b ore type discrimination clinopyroxene triangular diagram (Zuo et al. 2015); c ore type discrimination garnet triangular diagram (Zuo et al. 2015) 
chalcopyrite) and carbonates (calcite) replaced the earlyformed anhydrous calc-silicates. Magnetite is the most abundant ore mineral that formed during this stage.

Acknowledgments This research was made possible by the grant of the office of the vice chancellor for research and technology, University of Zanjan. We acknowledge their support. The manuscript significantly benefited from a thorough review and constructive comments by $\mathrm{E}$. Schingaro and another anonymous reviewer, and careful editorial work by Abdullah M. Al-Amri, Editor in Chief of the Arabian Journal of Geosciences.

Open Access This article is distributed under the terms of the Creative Commons Attribution 4.0 International License (http:// creativecommons.org/licenses/by/4.0/), which permits unrestricted use, distribution, and reproduction in any medium, provided you give appropriate credit to the original author(s) and the source, provide a link to the Creative Commons license, and indicate if changes were made.

\section{References}

Agard P, Omrani J, Jolivet L, Mouthereau F (2005) Convergence history across Zagros (Iran): constraints from collisional and earlier deformation. Int J Earth Sci 94:401-419

Agard P, Omrani J, Jolivet L, Whitechurch H, Vrielynck B, Spakman W, Moni EP, Meyer B, Wortel R (2011) Zagros orogeny: a subductiondominated process. Geol Mag 148:692-725

Aghazadeh M, Castro A, Rashidnejhad Omran N, Emami MH, Moinvaziri H, Badrzadeh Z (2010) The gabbro (shoshonitic)monzonite- granodiorite association of Khankandi pluton, Alborz Mountains, NW Iran. J Asian Earth Sci 38:199-219

Aghazadeh M, Badrzadeh Z, Castro A (2015) Petrogenesis and U-Pb (SHRIMP) dating of Tarom intrusions. Geosci Sci Quar J 24(95): 3-20 (In Persian with English abstract)

Alavi M (1994) Tectonics of the Zagros orogenic belt of Iran: new data and interpretations. Tectonophysics 229:211-238

Alavi M (2004) Regional stratigraphy of the Zagros fold-thrust belt of Iran and its proforeland evolution. Am J Sci 304:1-20

Alavi M (2007) Structures of the Zagros fold-thrust belt in Iran. Am J Sci 307:1064-1095

Andarz F (2006) Investigation of mineralogy and controlling factors of iron skarn mineralization of magnesium type in the mineralized region of Arjin, east of Zanjan (Zanjan province). Unpublished MSc Thesis, Islamic Azad University, Science Research Branch. (In Persian with English abstract)

Armbruster T, Birrer J, Libowitzky E, Beran A (1998) Crystal chemistry of Ti-bearing andradites. Eur J Mineral 5:907-921

Arvin M, Pan Y, Dargahi S, Malekizadeh A, Babaei A (2007) Petrochemistry of the Siah-Kuh granitoid stock southwest of Kerman, Iran: implications for initiation of Neo-Tethys subduction. J Asian Earth Sci 30:474-489

Ashrafi N, Ameri A, Jahangiri A, Hasebe N, Eby GN (2009) Mineral chemistry of garnets in the Kaleybar alkaline igneous intrusion, NW Iran. Iran J Crystal Mineral 17:357-368 (In Persian with English abstract)

Asiabanha A, Foden J (2012) Post-collisional transition from an extensional volcano- sedimentary basin to a continental arc in the Alborz Ranges, N Iran. Lithos 148:98-111

Barton PB, Skinner BJ (1967) Sulfide mineral stabilities. In: Barnes HL (Ed.), Geochemistry of Hydrothermal Ore Deposits, Holt, Rinehartand Winston, NewYork

Baghban S, Hosseinzadeh MR, Moayyed M, Mokhtari MAA, Gregory D (2015) Geology, mineral chemistry and formation conditions of calc-silicate minerals of Astamal Fe-LREE distal skarn deposit, Eastern Azarbaijan Province, NW Iran. Ore Geol Rev 68:79-96

Baghban S, Hosseinzadeh MR, Moayyed M, Mokhtari MAA, Gregory D, Mahmoudi Nia H (2016) Chemical composition and evolution of the garnets in the Astamal Fe-LREE distal skarn deposit, QaraDagh-Sabalan metallogenic belt, Lesser Caucasus, NW Iran. Ore Geol Rev 78:166-175

Baharifar A, Moinvaziri H, Bellon H, Piqué A (2004) The crystalline complexes of Hamadan (Sanandaj-Sirjan zone, western Iran): metasedimentary Mesozoic sequences affected by Late Cretaceous tectono-metamorphic and plutonic events. Compt Rendus Geosci 336:1443-1452

Berberian F, Berberian M (1981) Tectono- plutonic episodes in Iran. In: Gupta HK, Delany FM (eds) Zagros- Hindu Kush-Himalaya geodynamic evolution, vol 3. Geodynamics Series, American Geophysical Union, Washington DC, pp 5-32

Berberian M, King GCP (1981) Towards a paleogeography and tectonic evolution of Iran. Can J Earth Sci 18:210-265

Berberian F, Muir ID, Pankhurst RJ, Berberian M (1982) Late Cretaceous and early Miocene Andean type plutonic activity in northern Makran and central Iran. J Geol Soc Lond 139:605-614

Berman RG, Brown TH, Greenwood HJ (1985) An internally consistent thermodynamic data base for minerals in the system $\mathrm{Na}_{2} \mathrm{O}-\mathrm{K}_{2} \mathrm{O}$ $\mathrm{CaO}-\mathrm{MgO}-\mathrm{FeO}-\mathrm{SiO}_{2}-\mathrm{Al}_{2} \mathrm{O}_{3}-\mathrm{Fe}_{2} \mathrm{O}_{3}-\mathrm{TiO}_{2}-\mathrm{H}_{2} \mathrm{O}-\mathrm{CO}_{2}$. Atomic Energy of Canada Technical Report, TR-337, 62 pp

Berger J, Femenias O, Mercier JCC, Demaiffe D (2005) Ocean floor hydrothermal metamorphismin, Limousin ophiolites (Western French Massif Central): evidence of a rare preserved Variscan oceanic marker. J Metamorph Geol 23:795-812.

Besharati S, Nabatian Gh, Sadeghi A (2010) Skarn mineralization in the Arjin region (Southwest Soltanieh). The $1^{\text {th }}$ Conference of the Iranian Economic Geological Society, Mashhad, Ferdowsi University of Mashhad (In Persian with English abstract)

Burnham CW (1979) Magmas and hydrothermal fluids. In: Barnes HL (ed) Geochemistry of hydrothermal ore deposits. Wiley, New York, pp 71-136

Burt DM (1972) Mineralogy and geochemistry of Ca-Fe-Si skarn deposits. Unpublished $\mathrm{PhD}$ thesis, Harvard University, $256 \mathrm{pp}$.

Candela PA, Piccoli PL (1995) Model ore-metal partitioning from melt into vapor and vapor/brine mixtures. In: Thompson JFH (ed) Magmas, fluids and ore deposits. Miner Assoc of Canada Short Course, Handbook. 23:101-127

Chavideh M, Tabatabaei Manesh SM, Mackizadeh MA (2018) Petrology of skarns in the north and the southwest of Qazan (South Qamsar) with emphasis on the mineral chemistry of garnet and pyroxene. Petrology 33:111-132 (In Persian with English abstract)

Chiu HY, Chung SL, Zarrinkoub MH, Mohammadi SS, Khatib MM, Iizuka Y (2013) Zircon U-Pb age constraints from Iran on the magmatic evolution related to Neotethyan subduction and Zagros orogeny. Lithos 162-163:70-87

Clechenko C, Valley JW (2003) Oscillatory zoning in garnet from the Willsboro wollastonite skarn, Adirondack Mts., New York: a record of shallow hydrothermal and processes preserved in a granulite facies terrain. J Metamorph Geol 21:771-784

Cline JS, Bodnar RJ (1991) Can economic porphyry copper mineralization be generated by a typical calc-alkaline melt? J Geophys Res 96: 8113-8126

Deer WA, Howie RA, Zussman J (1992) An introduction to the rockforming minerals, 2nd edn. Longman $696 \mathrm{pp}$

Dingwell DB, Brearley M (1985) Mineral chemistry of igneous melanite garnets from analcite-bearing volcanic rocks, Alberta, Canada. Contrib Mineral Petrol 90:29-35

Einaudi MT (1982a) General features and origin of skarns associated with porphyry copper plutons. In: Titley SR (ed) Advances in geology of porphyry copper deposits. Tucson, Southwestern North America, University of Arizona Press, pp 185-210 
Einaudi MT (1982b) Descriptions of skarns associated with porphyry copper plutons. In: Titley SR (ed) Advances in geology of porphyry copper deposits. Tucson, Southwestern North America, University of Arizona Press, pp 1592-1606

Einaudi MT, Burt DM (1982) Introduction, terminology, classification, and composition of skarn deposits. Econ Geol 77:745-754

Einaudi MT, Meinert LD, Newberry RJ (1981) Skarn deposits. Econ Geol, 75th Anniversary volume, pp 317-391.

Fakhre Shafaie E, Mokhtari MAA, Ebrahimi M, Kouhestani H (2015) Geological and mineralization characteristics of Khakriz-Bagh Kandi iron deposit, SW Zanjan. The $33^{\text {th }}$ symposium on geosciences, Geological Survey of Iran. (In Persian with English abstract).

French BM, Eugster HP (1965) Experimental control of oxygen fugacities by graphite-gas equilibriums. J Geoph Res 70(6): 1529-1539.

Gaspar M, Knaack C, Meinert LD, Moretti R (2008) REE in skarn systems: a LA-ICP-MS study of garnets from the Crown Jewel gold deposit. Geochim Cosmochim Acta 72(1):185-205

Greenwood HJ (1967) Woiiastonite: Stability in H2O-CO2 mixtures and occurrence in a contact metamorphic aureole near Salmo, British Columbia, Canada. Am Mineral 52: 1669-1680.

Ghasemi A, Talbot CJ (2006) A new tectonic scenario for the SanandajSirjan zone (Iran). J Asian Earth Sci 26:683-693

Ghorbani M (2013) The economic geology of Iran: mineral deposits and natural resources. Springer, London, p 569

Grigoryev NA, Sazonov VN, Murzin VV, Gladkovskiy V (1990) Sulfides as gold carriers in skarn magnetite deposit skarns and ores. Geochem Int 27:142-146

Gustafson WI (1974) The stability of andradite, hedenbergite, and related minerals in the system Ca-Fe-Si-O-H. J Petr 15: 455-496.

Hamidvand M, Ebrahimi M, Mokhtari MAA, Nabatian Gh (2015) Petrographical and mineralogical studies of Incheh- Rahbari Fe deposit, south Zanjan. The $33^{\text {th }}$ symposium on geosciences, Geological Survey of Iran. (In Persian with English abstract)

Harris NB, Einaudi MT (1982) Skarn deposits in Yerington district, Nevada: metasomatic skarn evolution near Ludwig. Econ Geol 77: 877-898

Hassanzadeh J, Wernicke BP (2016) The Neotethyan Sanandaj-Sirjan zone of Iran as an archetype for passive margin-arc transitions. Tectonics 35:586-621

Hassanzadeh J, Stockli DF, Horton BK, Axen GJ, Stockli LD, Grove M, Schmitt AK, Walker JD (2008) U-Pb zircon geochronology of late Neoproterozoic-Early Cambrian granitoids in Iran: implications for paleogeography, magmatism, and exhumation history of Iranian basement. Tectonophysics 451:71-96

Hedenquist JW, Arribas JA, Renolds TJ (1998) Evolution of an intrusioncentered hydrothermal system. Far southeast-Lepanto porphyry and epithermal $\mathrm{Cu}-\mathrm{Au}$ deposits, Philippines. Econ Geol 93:373-404

Heimann A, Spry PG, Teale GS, Conor CHH, Leyh WR (2009) Geochemistry of garnet-rich rocks in the Southern Curnamona province, Australia and their genetic relationship to Broken Hill-type $\mathrm{Pb}$ Zn-Ag mineralization geology. Econ Geol 104:687-712

Helgeson HC (1969) Thermodynamics of hydrothermal systems at elevated temperatures and pressures. Am J Sci 267(7): 729-804.

Honarmand M, Rashidnejhad Omran N, Neubauer N, Emami MH, Nabatian G, Liu X, Donge Y, Von Quadt A, Chen B (2014) LaserICP-MS U-Pb zircon ages and geochemical and $\mathrm{Sr}-\mathrm{Nd}-\mathrm{Pb}$ isotopic compositions of the Niyasar plutonic complex, Iran: constraints on petrogenesis and tectonic evolution. Int Geol Rev 56:104-132

Honarmand M, Xiao W, Nabatian G, Blades ML, Dos Santos MC, Collins AS, Ao S (2018) Zircon U-Pb-Hf isotopes, bulk-rock geochemistry and $\mathrm{Sr}-\mathrm{Nd}-\mathrm{Pb}$ isotopes from late Neoproterozoic basement in the Mahneshan area, NW Iran: implications for Ediacaran active continental margin along the northern Gondwana and constraints on the late Oligocene crustal anataxis. Gondwana Res 57: $48-76$
Hosseini NA (2008) Exploration report of Qozlou Fe deposit. Ministry of Industry, Mine and Trade, Zanjan Province. (In Persian)

Robie RA (1968) Thermodynamic propertiesof minerals and related subsances at $298.15 \mathrm{~K}(25.0)$ and one atmosphere (1.013 bars) pressure and at higher temperatures. US Geol Surv Bull, 1259.

Huggins FE, Virgo D, Huckenholz HG (1977) Titanium containing silicate garnets II, the crystal chemistry of melanites and schorlomites. Am Mineral 62:646-665

Jamtveit B (1997) Crystal growth and intercrystalline zonation patterns in hydrothermal system. In: Jamtveit B, Meakin P (eds) Growth and dissolution and pattern formation in geosystems, Netherland. Am Mineral, Kluwer Academic. 76:65-82.

Kesler SE (1968) Contact-localized ore formation in the Memé mine, Haiti. Econ Geol 63:541-552

Liou JG (1974) Stability relations of andradite-quartz in the system CaFe-Si-O-H. Am Mineral 59: 1016-1025.

Lotfi M (2001) Geological map of Mahneshan, sheet no. 5563, scale 1: 100,000, Geological Survey of Iran

Maanijou M, Salemi R (2014) Mineralogy, chemistry of magnetite and genesis of Korkora-1 iron deposit, east of Takab, NW Iran. J Ecol Geol 6(2):355-374 (In Persian with English abstract)

Meinert LD (1992) Skarn and skarn deposits. Geosci Can 19:145-162

Meinert LD (1995) Compositional variation of igneous rocks associated with skarn deposits- chemical evidence for a genetic connection between petrogenesis and mineralization. In: Thompson JFH (ed) Magmas, fluids and ore deposits. Miner Assoc of Canada, Short Course Series, 23:400-418.

Meinert LD (1997) Application of skarn deposit zonation models to mineral exploration. Explor Min Geol 6:185-208

Meinert LD (2000) Gold in skarns related to epizonal intrusions. Rev Econ Geol 13:347-375

Meinert LD, Hedenquist JW, Satoh H, Matsuhisa Y (2003) Formation of anhydrous and hydrous skarn in $\mathrm{Cu}-\mathrm{Au}$ ore deposits by magmatic fluids. Econ Geol Bull Soc Econ Geol 98:47-156

Meinert LD, Dipple GM, Nicdescu S (2005) World skarn deposits. 100th Anniversary volume. Eco Geol 299-336

Micko J, Tosdal RM, Bissig T, Chamberlain CM, Simpson KA (2014) Hydrothermal alteration and mineralization of the Galore Creek alkalic $\mathrm{Cu}-\mathrm{Au}$ porphyry deposit, Northwestern British Columbia, Canada. Econ Geol 109(4):891-914

Mohajjel M, Fergusson CL, Sahandi MR (2003) Cretaceous-Tertiary convergence and continental collision, Sanandaj-Sirjan Zone, western Iran. J Asian Earth Sci 21:397-412

Mohammad Beigi N, Mokhtari MAA, Kouhestani H, Jamali H (2016) Geological and mineralogical characteristics of Qovaq Fe deposit, southwest Dandy (Zanjan Province). The $8^{\text {th }}$ symposium on Economic Geology, University of Zanjan, Iran. (In Persian with English abstract).

Mohammadi F (2013) Mineralogy, geochemistry and genesis of Qozal Darreh Fe deposit (SE Zanjan). Unpublished MSc. Thesis, Payam Noor University, Tehran Branch. (In Persian with English abstract)

Mokhtari MAA (2012) The mineralogy and petrology of Pahnavar Fe skarn in the Eastern Azarbaijan, NW Iran. Cen Eur J Geol 4(4):578 591

Mokhtari MAA, Kouhestani H, Pang KN, Chung SL (2018) Age and geochemical constraints on granitoid petrogenesis in the KhorramDarag-Khakriz Region $\left(36.5^{\circ} \mathrm{N}, 48.5^{\circ} \mathrm{E}\right)$, Urumieh-Dokhtar Magmatic Arc, NW Iran. 8th Geochemistry Symposium, Antalya, Turkey, p. 100

Nabatian G, Ghaderi M, Neubauer F, Honarmand M, Lui X, Dong Y, Jiang SY, Bernroider M (2014) Petrogenesis of Tarom high-potassic granitoids in the Alborz-Azarbaijan belt, Iran: geochemical, U-Pb zircon and $\mathrm{Sr}-\mathrm{Nd}-\mathrm{Pb}$ isotopic constraints. Lithos 184-187:324-345

Nabatian G, Rastad E, Neubauer F, Honarmand M, Ghaderi M (2015) Iron and $\mathrm{Fe}-\mathrm{Mn}$ mineralization in Iran: implications for Tethyan metallogeny. Aus J Earth Sci 62:211-241 
Nabatian G, Li XL, Honarmand M, Melgarejo JC (2017) Geology, mineralogy and evolution of iron skarn deposits in the Zanjan district, NW Iran: constraints from $\mathrm{U}-\mathrm{Pb}$ dating, $\mathrm{Hf}$ and $\mathrm{O}$ isotope analyses of zircons and stable isotope geochemistry. Ore Geol Rev 84:42-66

Nakano T, Yoshino T, Shimazaki H, Shimizu M (1991) Pyroxene composition as an indicator in the classification of skarn deposits. Econ Geol 89:1567-1580

Nouri F, Mokhtari MAA, Izadyar J, Kouhestani H (2017) Geological and mineralogical characteristics of Alamkandi Fe deposit, west of Zanjan. The $35^{\text {th }}$ symposium on geosciences, Geological Survey of Iran (In Persian with English abstract).

Omrani J, Agard P, Whitechurch H, Benoit M, Prouteau G, Jolivet L (2008) Arc magmatism and subduction history beneath the Zagros Mountains, Iran: a new report of adakites and geodynamic consequences. Lithos 106:380-398

Papike JJ, Shearer CK, Ryder G (1998) Lunar samples. In: Papike JJ (Ed.), Planetary Materials. Rev Mineral 36: 5-1-5-234.

Perkins EH, Brown TH, Berman RG (1986) PTX-SYSTEM: Three programs for calculation of pressure- temperature-composition phase diagrams. Comput Geosci 12:749-755

Pirajno F (2009) Hydrothermal processes and mineral systems. Springer, Berlin $1250 \mathrm{pp}$

Ramezani J, Tucker RD (2003) The Saghand region, central Iran: U-Pb geochronology, petrogenesis and implications for Gondwana tectonics. Am J Sci 303(7): 622-665.

Ray GE, Webster ICL, Ettlinger AD (1995) The distribution of skarns in British Columbia and the chemistry and ages of their related plutonic rocks. Econ Geol 90:920-937

Richards JP, Wilkinson D, Ullrich T (2006) Geology of the Sari Gunay epithermal gold deposit, northwest Iran. Econ Geol 101:455-1496

Russell JK, Dipple GM, Lang JR, Lueck B (1999) Major element discrimination of titanian andradites from magmatic and hydrothermal environments: an example from the Canadian Cordillera. Eur J Mineral 6:919-935

Schingaro E, Lacalamita M, Mesto E, Ventruti G, Pedrazzi G, Ottolini L, Scordari F (2016) Crystal chemistry and light elements analysis of Ti-rich garnets. Am Mineral 101:71-384

Scott SD, Barnes HL (1971) Sphalerite geothermometry and geobarometry. Eco Geol 66(4): 653-669.

Șengör AMC (1990) A new model for the late Paleozoic-Mesozoic tectonic evolution of Iran and implications for Oman. In: Robertson AHF, Searle MP, Ries AC (ed) The geology and tectonics of the Oman Region. London, UK. Geological Society of London, Special Publications, 797-831

Șengör AMC, Altiner D, Cin A, Ustaömer T, HsüK J (1988) The origin and assembly of the Tethyside orogenic collage at the expense of Gondwana land. In: Audley-Charles MG, Hallam A (eds)
Gondwana and Tethys 37. Geological Society of London, Special Publication, London, pp 119-181

Shafaiepour N (2018) Petrology and geochemistry of Qozlou granitoid (west of Zanjan) and its contact metamorphic aureole. Unpublished MSc. Thesis, University of Zanjan. (In Persian with English abstract)

Shafaiepour N, Mokhtari MAA, Kouhestani H, Honarmand M (in press) Petrology and geochemistry of Qozlou granitoid and Fe skarn deposit (west Zanjan). J Ecol Geol (In Persian with English abstract)

Shahabpour J (2005) Tectonic evolution of the orogenic belt in the region located between Kerman and Neyriz. J Asian Earth Sci 24:405-417

Shahbazi S, Ghaderi M, Rashidnejhad Omran N (2015) Mineralization stages and iron source of Bashkand deposit based on mineralogy, structure, texture and geochemical evidence, Southwest of Soltanieh. Geosci Sci Quar J 24(95):355-372 (In Persian with English abstract)

Shinohara H, Kazahaya K (1995) Degassing processes related to magma chamber crystallization. In: Thompson JFH (ed) Magmas, fluids and ore deposits. Miner Assoc Canada Short Course, Handbook, 23:4770

Sweeney ML (1980) Geochemistry of garnets from the North Ore shoots, Bingham district, Utah. Unpublished MSc Thesis, University of Utah, $154 \mathrm{pp}$

Takin M (1972) Iranian geology and continental drift in the Middle East. Nature 23:147-150

Taylor BE, O’Neil JR (1977) Stable isotope studies of metasomatic Ca$\mathrm{Fe}-\mathrm{Al}-\mathrm{Si}$ skarns and associated metamorphic and igneous rocks, Osgood Mountains, Nevada. Contrib Mineral Petrol 63:1-49

Taylor BE, Liou JG (1978) The low-temperature stability of andradite in COH fluids. Am Mineral 63(3-4): 378-393.

Uchida E (1983) Grunerite from the Shinyama ore deposit, Kamaishi mine, Japan. Can Mineral 21:517-528

Verdel C, Wernicke BP, Hassanzadeh J, Guest B (2011) A Paleogene extensional arc flare-up in Iran. Tectonics 30:TC3008. https://doi. org/10.1029/2010TC002809

Vidal CE, Injoque-Espinoza J, Sidder GB, Mukasa SB (1990) Amphibolitic $\mathrm{Cu}-\mathrm{Fe}$ skarn deposits in the central coast of Peru. Econ Geol 85:1447-1461

Wones DR, Eugster HP (1965) Stability of biotite: Experiment, theory and application. Am Mineral 50: 1228-1272.

Zheng J, Mao JW, Fuquan Yang F, Liu F, Zhu YF (2015) The postcollisional Cihai iron skarn deposit, eastern Tianshan, Xinjiang, China. Ore Geol Rev 67:244-254

Zuo P, Liu X, Hao J, Wang Y, Zhao R, Ge S (2015) Chemical compositions of garnet and clinopyroxene and their genetic significances. J Geochem Explor 158:143-154 